\title{
Conflict Resolution in Insect Societies
}

\author{
Francis L.W. Ratnieks, ${ }^{1,2}$ Kevin R. Foster, ${ }^{2}$ \\ and Tom Wenseleers ${ }^{2,3}$
}

${ }^{1}$ Laboratory of Apiculture and Social Insects, Department of Animal and Plant Sciences, University of Sheffield, Sheffield S10 2TN, United Kingdom; email: f.ratnieks@sheffield.ac.uk

${ }^{2}$ Institute for Advanced Study, 14193 Berlin, Germany; email: kevin.foster@wiko-berlin.de ${ }^{3}$ Laboratory of Entomology, Zoological Institute, University of Leuven, 3000 Leuven, Belgium; email: tom.wenseleers@bio.kuleuven.ac.be

Key Words social insects, social Hymenoptera, social evolution, reproductive conflict

- Abstract Although best known for cooperation, insect societies also manifest many potential conflicts among individuals. These conflicts involve both direct reproduction by individuals and manipulation of the reproduction of colony members. Here we review five major areas of reproductive conflict in insect societies: $(a)$ sex allocation, $(b)$ queen rearing, $(c)$ male rearing, $(d)$ queen-worker caste fate, and $(e)$ breeding conflicts among totipotent adults. For each area we discuss the basis for conflict (potential conflict), whether conflict is expressed (actual conflict), whose interests prevail (conflict outcome), and the factors that reduce colony-level costs of conflict (conflict resolution), such as factors that cause workers to work rather than to lay eggs. Reproductive conflicts are widespread, sometimes having dramatic effects on the colony. However, three key factors (kinship, coercion, and constraint) typically combine to limit the effects of reproductive conflict and often lead to complete resolution.

\section{INTRODUCTION}

Observation of an insect society readily reveals cooperation. Workers actively work for the good of the colony as they forage, guard, build, and nurse. Detailed study reinforces this impression. Workers cooperate to forage and defend by means of sophisticated communication signals $(56,113)$. In some species cooperation includes extreme altruism, with defending workers sacrificing their lives as they deploy detachable stings or chemical-filled exploding abdomens to deter intruders $(56,113)$. However, sophisticated cooperation in one area of social life does not preclude conflict in another. Egg laying, brood rearing, and queen-worker caste development, for example, can all be associated with significant conflict. Indeed, potential conflict in insect societies is inevitable because insect societies are almost always families, not clones. Nevertheless, conflict in insect colonies is less obvious 
than cooperation, which suggests that conflict may often be resolved or weak. What factors enable insect societies to resolve their conflicts? In this review, we discuss the large body of work devoted to this question, which has focused primarily on the eusocial Hymenoptera (bees, ants, and wasps).

\section{INCLUSIVE FITNESS THEORY: EXPLANATION FOR BOTH COOPERATION AND CONFLICT}

Inclusive fitness theory (47) provides a general explanation for reproductive division of labor in eusocial insects, with some individuals forgoing direct reproduction to help rear the offspring of other colony members. The intermediate levels of relatedness typically found in insect societies provide a strong incentive for altruism, and kin are also close at hand and can readily be helped by defense or food collection. Ironically, the same theory also led to the realization that insect societies are subject to internal conflicts over reproduction. Even when family relatedness is at its highest, kinship is insufficient to eliminate all incentive for individual selfishness. This would require a relatedness of 1 . At lower relatedness levels, social groups are vulnerable to exploitation by group members who free ride on group resources $(51,61)$. The challenge for evolutionary biology is to understand how groups can prevent or reduce such exploitation. This problem is a general one, as it applies not just to insect societies but across all levels of biological organization, from intragenomic conflicts (57) to conflicts among partner organisms in multispecies mutualisms $(71,109)$. Insect societies are arguably the leading model system for investigating this puzzle, and inclusive fitness theory has provided great insight into the factors that can cause or resolve conflict in their colonies. In fact, while some of the conflicts that occur in insect societies can also be described using a multilevel selection approach $(64 \mathrm{~b}, 134,136)$, it is fair to say that most of the insight has come from inclusive fitness theory. Hence, all discussion in this paper will be couched in inclusive fitness terms. For those wishing to see analyses worked out using an equivalent multilevel selection approach, readers are referred to References 134 and 136.

Empirical study of conflict within insect societies began with Trivers \& Hare (125), who used inclusive fitness theory to show that there is potential conflict between mother queen and daughter workers over the rearing of young males versus queens in eusocial Hymenoptera. Because of their haplodiploid genetics (females are diploid, males are haploid) (17), female hymenopteran workers are three times more related to full sisters $(r=0.75)$ than to brothers $(r=0.25)$, whereas the queen is equally related to sons and daughters $(r=0.5)$. As a result, the queen optimum is an even allocation ratio, whereas the worker optimum is biased three to one in favor of females. Trivers \& Hare's analysis (125) supported the prediction of female bias, although later studies have shown that female bias is frequently less than three to one $(8,54)$. The Trivers \& Hare study was of great importance in providing support for inclusive fitness theory, and their conclusions 
undermined the traditional view of an insect society as a harmonious entity with a ruling queen. Instead, the ant queen even came to be seen as farmed by the workers as an egg source (31).

Sex allocation is only one of several major areas of reproduction in insect societies. Researchers have documented conflict over male rearing $(13,49,95,125$, $136,139)$, queen rearing $(47,60,97,124,127)$, female caste fate $(18,106,138$, $140,141)$, and, in societies lacking morphologically distinct queens and workers, queen status (76) and the choice between helping and nesting independently (103). All conflicts revolve around reproduction, especially breeding, egg laying, and brood rearing, and often involve actions that change the balance between direct, personal reproduction and indirect reproduction by other colony members. For example, workers, and females in general, can attempt to increase their personal reproduction by laying eggs $(13,49,136,139)$, by developing into a queen rather than into a worker $(18,106,140)$, or, in species without morphological castes, by overthrowing the existing queen $(76,77)$ or nesting independently $(103)$. However, workers may also enhance their inclusive fitness by shifting reproduction toward a more valuable class of relatives (42a) such as by favoring sisters over brothers (125) or queen's sons over workers' sons (95).

Mating is rarely a source of intracolony conflict because mating is rarely part of social life. Queens mate when young and store sufficient sperm to last their whole life. As a result, male-male conflict over mating, which can be a major feature in vertebrate societies, is generally absent within an insect society, although mating conflicts do occur outside the colony (9). One example of within-nest mating conflict occurs in Cardiocondyla ants, which have males of two morphological types. Worker-like wingless males mate inside the nest and fight and kill each other with their sharp mandibles. Winged males mate mainly outside the nest and evade physical competition with the wingless males by chemically mimicking females (26).

\section{WHAT DO WE MEAN BY CONFLICT RESOLUTION?}

Potential conflict is any difference in the reproductive optima of individuals or groups within a society (100). Thus, there is potential worker-queen conflict over colony sex allocation ratio, but there is no worker-worker conflict because all workers have the same optimum. Actual conflict is overt conflict among individuals with different optima (100). For example, there is actual conflict when the workers kill some of the queen's male offspring to cause a female-biased sex ratio.

The focus of this review is conflict resolution, not conflict in general, which has already been excellently reviewed elsewhere $(6,16 a, 17,28,93,100)$. Our goal is to identify factors that are responsible for reducing conflict from hypothetical worst-case scenarios to the levels actually seen. Consider, for example, the conflict over whether female larvae develop into queens or workers $(18,106,140)$ (Box S1; follow the Supplemental Material link from the Annual Reviews home page 
at http://www.annualreviews.org). Here, the worst-case scenario is that all female larvae selfishly develop into queens. However, the adult workers and queen benefit most from raising only as many new queens as the colony needs to reproduce (18, $106,140)$. In this example, the optimum of individual larvae, which results in many excess queens being reared, and the optimum of the adult workers, which results in zero excess queens, are both biologically plausible conflict outcomes. However, only the latter results in conflict resolution. We define conflict resolution as an outcome that reduces to a low level the proportion of the colony's resources that are wasted in the conflict. Resolution is not necessarily the same as winning. A conflict may be won at high cost. In Melipona bees, the female larvae win the conflict with the workers over their adult caste, with an excess developing into queens (135, 138). This diminishes the workforce and reduces colony reproduction (138).

A large body of research, known as skew theory, has focused on how reproduction is partitioned within societies (103). We do not focus on skew here because it is concerned principally with the conflict outcome rather than resolution. That is, both high-skew and low-skew (egalitarian) societies can be associated with well-resolved conflicts. For example, in caste fate conflict the colony optimum is often one of high skew, in which few individuals follow the selfish strategy of becoming a queen and most work for the good of the colony $(136,140)$. In other situations, however, a low-skew society may maximize productivity if, for instance, this minimizes aggression (103).

\section{KINSHIP, COERCION, AND CONSTRAINT}

Many factors can affect whether reproductive conflicts are resolved in insect colonies. We suggest that all are combinations of three underlying factors: kinship, coercion, and constraint.

Kinship refers not only to the relatedness among individuals but also to their familial relationships, such as mother-daughter or sister-sister. Kinship has several important basic effects (Figure 1). Because relatedness among individuals is typically lower than 1 , there is potential conflict within insect societies. However, depending on kin structure, there may not be potential conflict in particular areas of colony reproduction (Figure 1). For example, there is no conflict over queen rearing in a society with a single queen mated to a single male because all workers are equally related to all new queens. However, there is queen-worker conflict over sex allocation in a hymenopteran society of this kin structure but not in a termite society because termite workers are diploid and equally related to male and female siblings.

Where potential conflict does occur, kinship can affect resolution in multiple ways (Figure 1). Most fundamentally, low relatedness makes wasteful conflicts more likely because the cost of conflict falls upon more distant kin $(136,138,140)$. For example, in male-rearing conflict, low relatedness favors more egg laying by workers (136) (Box S1). However, low relatedness caused by multiple paternity can also select for workers to police each other, because under multiple paternity 


\section{Single paternity}
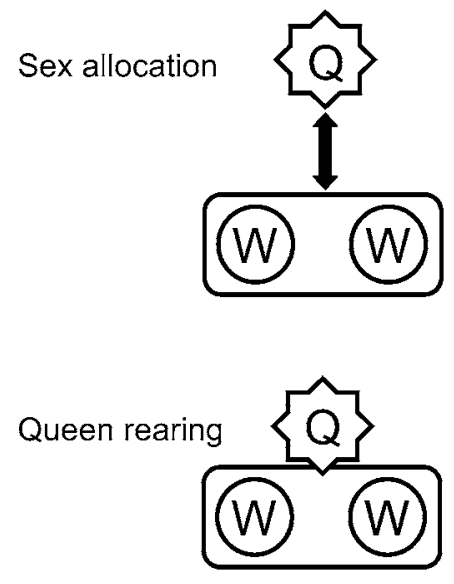

Male rearing

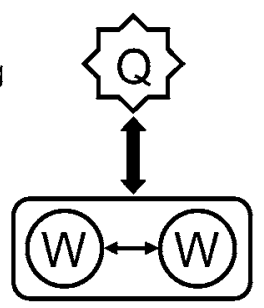

Caste fate

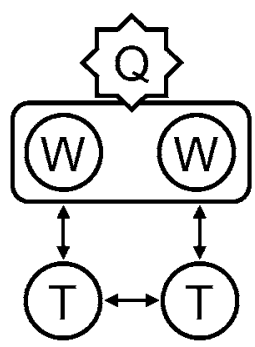

Multiple paternity
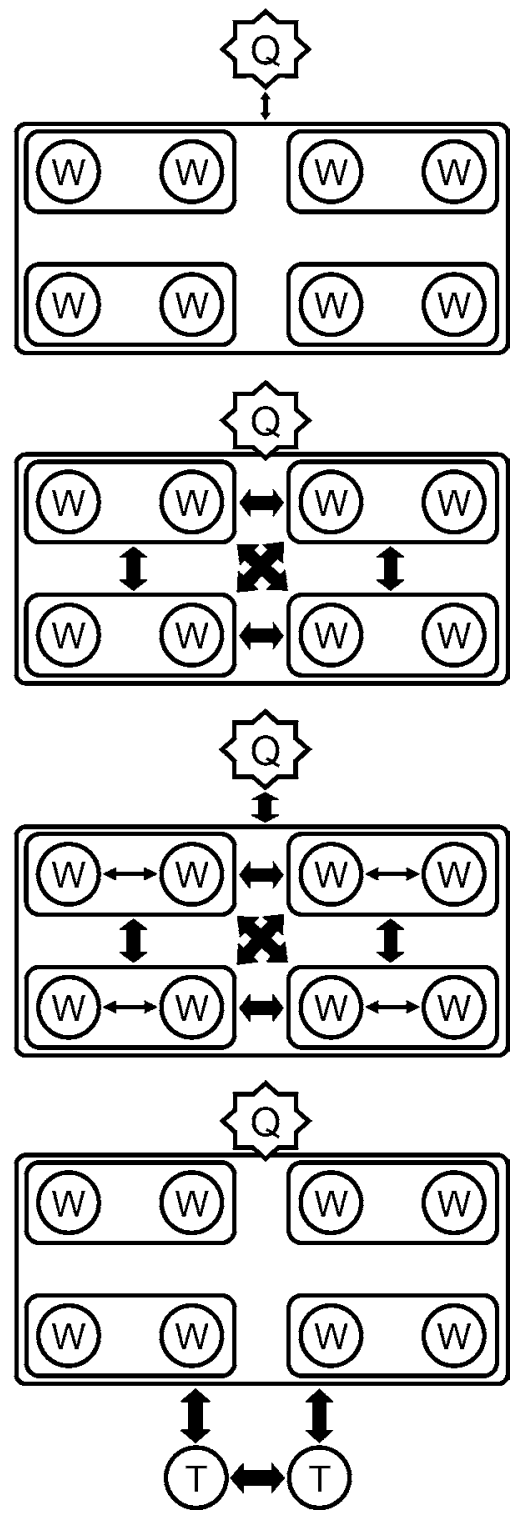

Figure 1 Potential conflict in hymenopteran societies headed by a single queen mated to a single male (left column) or four males (right column). The outer rectangle represents all the workers. The inner rectangles (right column) represent workers of different fathers. Arrows represent conflicts, and the width of the arrow is the relative strength of the conflict in relation to other arrows for that particular conflict. W, individual worker; $\mathrm{Q}$, queen; T, totipotent larval females. 
workers are more closely related to the queen's sons (brothers, $r=0.25$ ) than to other workers' sons (a mix of full- and half-nephews, $r<0.25$ ) (95). Hence, subtle differences in kinship can provide conditions that select one party to coerce another $(95,102)$. Coercion is the second major factor that can help resolve conflict, as it may prevent individuals from acting selfishly or reduce the benefit to do so (102, 134) (Figure 2). Nevertheless, coercion is not necessarily stable in the long run, since there will still be selection on individuals to evade coercion, and there are good examples of this occurring (Figure 3).

Finally, conflict may also be resolved through constraint. That is, individuals may just not have the possibility to act selfishly, or can do so only at very high cost $(64 b, 134)$. Coercion can often lead to constraints. For example, in the honey bee, female larvae in worker cells are coerced to become workers because they are given insufficient food to develop as queens. Thus, coercion causes constraints on the caste into which female larvae can develop. However, constraints can also be independent of coercion, for example, when they refer to genetic or other mechanistic constraints.

\section{SEX ALLOCATION}

\section{Basis for Conflict}

Potential conflict over sex allocation in hymenopteran societies is predominantly between the workers as a collective and the mother queen (Figure 1). In a panmictic population with colonies headed by a single, once-mated queen and no worker reproduction, the optimum investment in females (young queens) versus males is 1:1 for the mother queen and 3:1 for the workers. These differences result from haplodiploidy $(17,28,125)$, which causes the workers to be three times more related to full-sisters $(r=0.75)$ than to brothers $(r=0.25)$. As in normal diploidy, the queen is equally related to her sons and daughters. There is no potential conflict in termites, as they are diploid (125). There is also no potential conflict between the mother queen and the workers when the queen mates many times because offspring workers are then equally related to males (brothers, $\mathrm{r}=0.25$ ) and young queens (half-sisters, $r=0.25)(87,88)$. Potential conflict is also absent when all the males in the population are sons of workers $(87,125)$. Although observed levels of multiple mating $(12,117)$ or worker reproduction $(49,139)$ (Figure 4$)$ can approach these extremes, considerable potential conflict over sex allocation remains in most species $(87,88)$.

\section{Is There Actual Conflict?}

Trivers \& Hare (125) found that ant sex ratios were significantly female biased by approximately $3: 1(8,17,80)$. A later reanalysis of the Trivers \& Hare dataset, accounting for differences in the caloric content of males and queens (8), however, showed that female bias was actually less than 3:1 and thus intermediate between the queen and worker optima $(16 \mathrm{a}, 17,125)$. This is consistent with an ongoing 

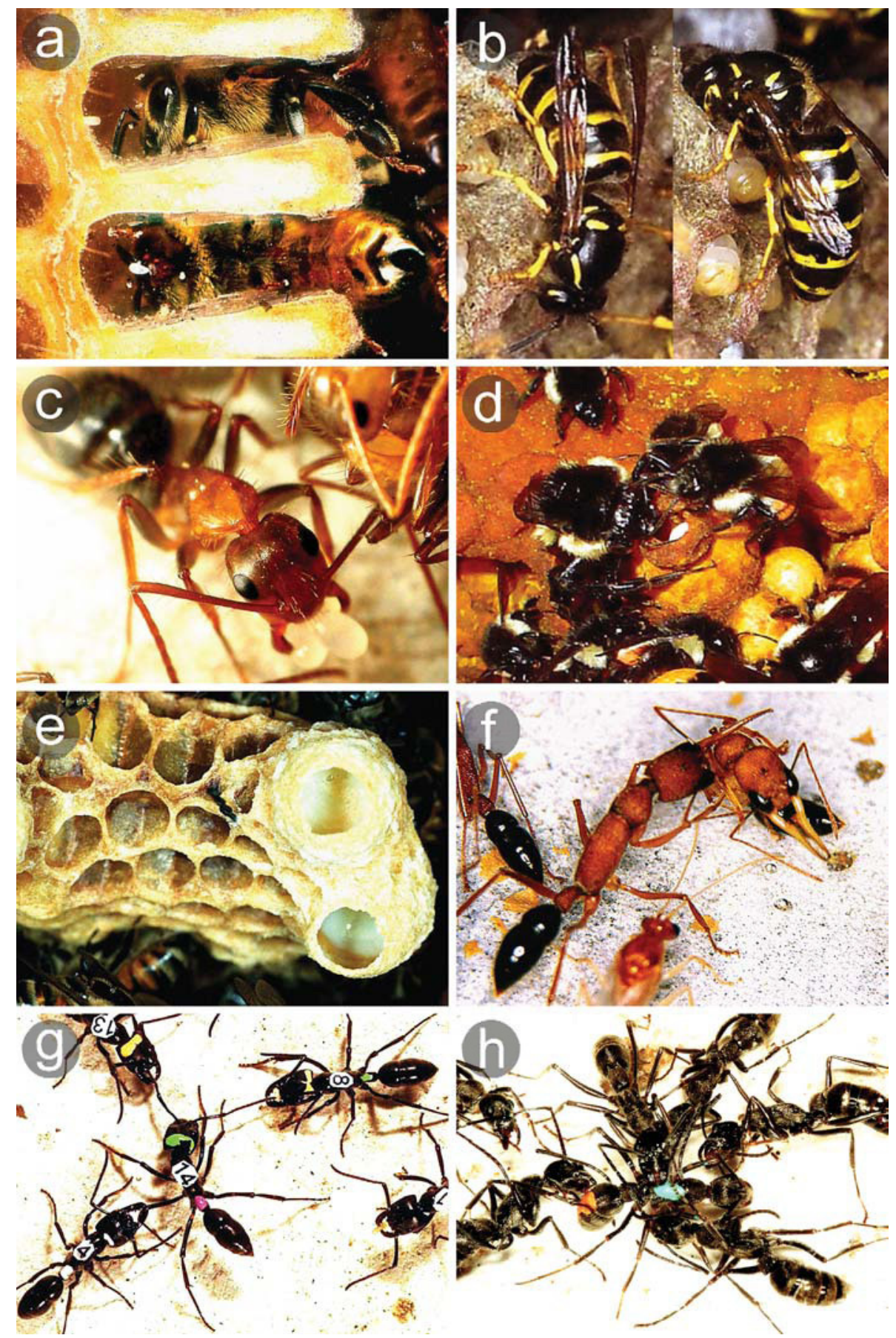

See legend on next page 
Figure 2 Examples of coercion resolving conflicts in insect societies. (a) Worker policing in the honey bee, A. mellifera. (b) A worker lays an egg and another one polices the egg in the saxon wasp, D. saxonica. (c) Worker policing in the ant C. floridanus. $(d)$ The queen (left) about to police a worker-laid egg in the bumble bee Bombus ephippiatus. (e) Differential feeding of worker-destined (left) and queen-destined (right) larvae in the honey bee, A. mellifera. $(f)$ Aggression toward a worker with active ovaries in the queenless ant Harpegnathos saltator. ( $g$ ) Punishment of a worker that attempted to overthrow the alpha breeder in the queenless ant Dinoponera quadriceps. ( $h$ ) Mutilation of thoracic appendages prevents newly eclosed workers from mating in the queenless ant Diacamma pallidum. Photos are by F.L.W. Ratnieks $(a, e)$, K.R. Foster $(b)$, J. Liebig $(c, f)$, J.I. CuadrielloAguilar $(d)$, T. Monnin $(g)$, and T. Wenseleers $(h)$. 


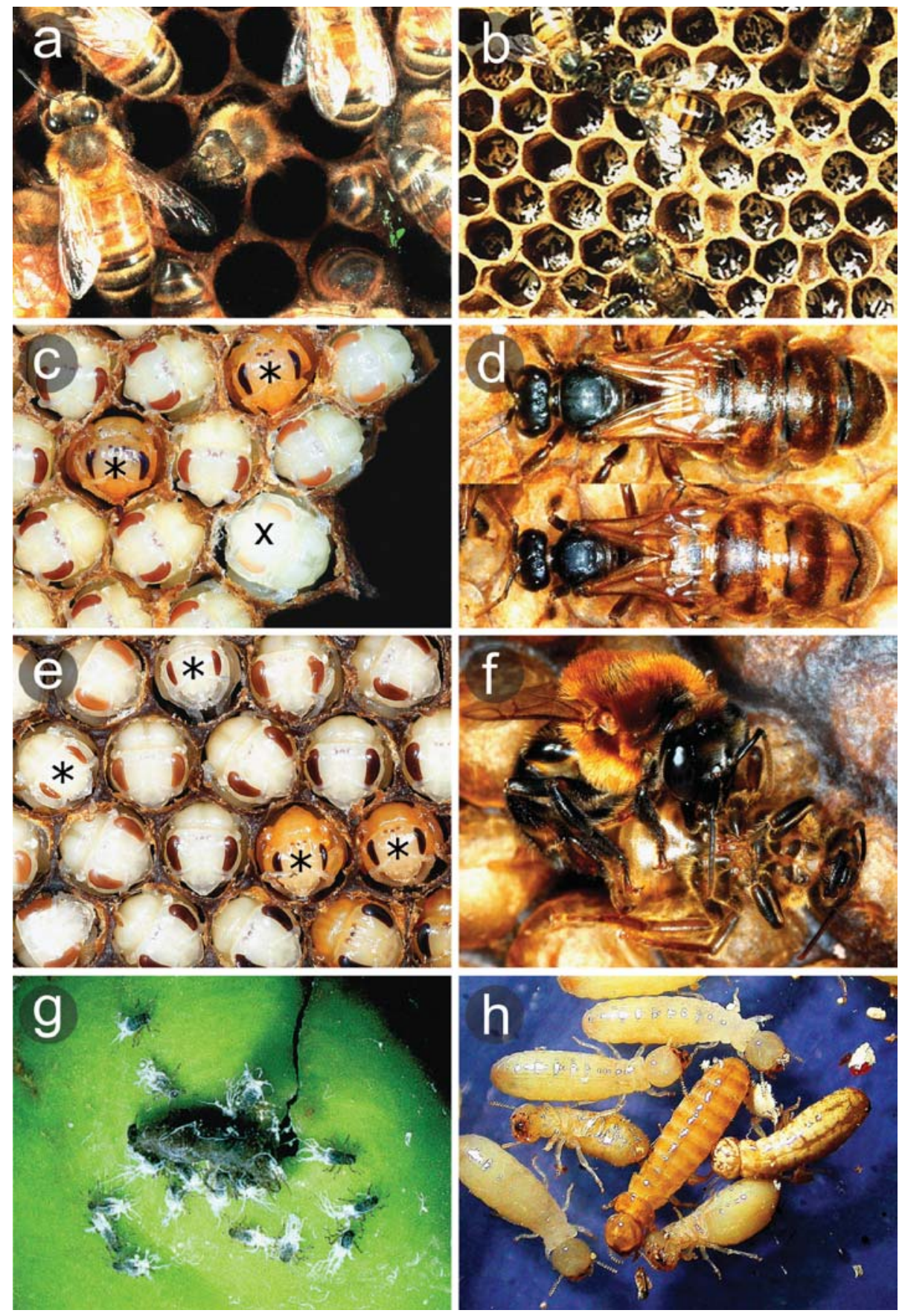

See legend on next page 
Figure 3 Examples in which coercion is either evaded or not possible, resulting in overt actual conflict. (a) An anarchistic worker honey bee lays an egg that mimics the smell of queen-laid eggs and thereby escapes from being policed. $(b)$ Parasitic Cape bee workers, A. mellifera capensis, also lay eggs that are not policed in colonies of their host, A. mellifera scutellata, resulting in the accumulation of a great excess of Cape bee eggs. (c) Opened brood comb of the stingless bee Schwarziana quadripunctata showing two females who selfishly developed as dwarf queens (*); the large royal cell at the periphery contains a normal-sized queen (x). (d) Like normal queens (top), dwarf Schwarziana queens (bottom) can successfully head a colony. (e) A great excess of females selfishly developed as queens $(*)$ in this opened brood comb of the stingless bee Melipona subnitida. $(f)$ An excess Melipona queen is killed by a worker (top). ( $g$ ) In the social gall aphid Pemphigus obesinymphae, soldiers of one gall invade those of another and then selfishly develop into alate reproductives. $(h)$ In the drywood termite Cryptotermes domesticus, individuals can determine their own caste because nymphs feed by themselves on the wood that forms their nest cavity. If the royal pair is removed, a great excess of individuals develop into replacement reproductives, but after fierce fights only a single pair (center) survives. Photos are by B.P. Oldroyd (a), S.J. Martin (b), T. Wenseleers $(c-f)$, N.A. Moran $(g)$, and J. Korb $(h)$. 


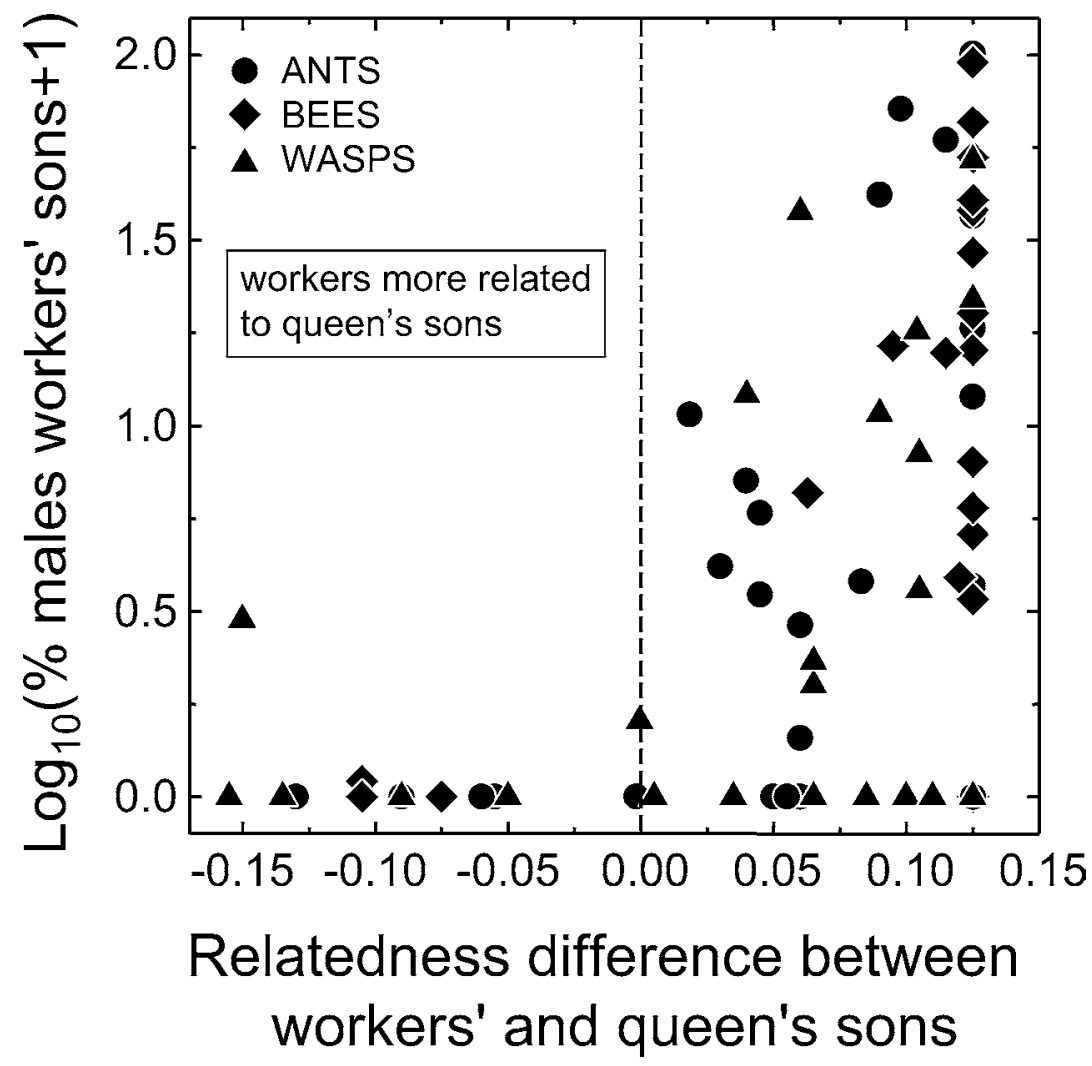

Figure 4 A significantly smaller proportion of the adult males are workers' sons in species in which workers are related more to the queen's sons than to other workers' sons (139). This is consistent with worker policing theory (95), which predicts that workers should eliminate other workers' sons when they are related more to those of the queen. This trend is also significant if phylogenetic nonindependence is controlled for (139). Data are from Reference 49, with additions and corrections as in Reference 139.

conflict in which both the queen and the workers possess some power over sex allocation $(72,105)$. In some species, allocation less extreme than $75 \%$ female may also be compatible with full worker control if the worker optimum is reduced by multiple mating by queens $(87,88)$, multiple related queens $(97,96)$, or worker production of males $(87,125)$.

Direct evidence for actual sex-ratio conflict comes from studies showing that the sex ratio among pupae or adults is more female biased than the sex ratio among the eggs laid by the queen $(4,48,62,89,122)$, implying that not all male eggs are reared. Sex-allocation conflict has also been well documented in species with split sex ratios, in which some colonies raise mostly males and others raise mostly females $(16 a, 93,121,122)$. In the wood ants Formica exsecta and 
F. truncorum, for example, queens can be singly or multiply mated $(121,122)$, and workers enhance their inclusive fitness by female specialization in colonies headed by a singly mated queen and by male specialization in colonies headed by a multiply mated queen $(10,96,121,122,123)$. In $F$. exsecta, there was no difference in the sex ratio of the eggs laid by singly mated and multiply mated queens (122). However, the pupal sex ratio was significantly more female biased than the egg sex ratio in colonies headed by a singly mated queen (122). Evidence for actual conflict was also found in the ant Leptothorax acervorum, in which single-queen colonies have a more female-biased sex allocation than multiplequeen colonies, which the workers achieve by rearing more female eggs as queens than as workers (48). Finally, several other ants, bees, and wasps also show split sex ratios, and in 19 of the 25 documented cases, sex ratios correlated with relatedness (16a). Again, this provides strong evidence for actual conflict and for worker control.

In a minority of cases, ant sex ratios have been found to be almost even, for example, in slave-making ants $(14,80,125)$ and in the ant Pheidole desertorum (54). In these cases, the queen appears to win the sex ratio conflict. In bumble bees, sex ratios may also be close to even or male biased, indicating queen control $(16,32 \mathrm{a})$.

\section{Conflict Resolution}

Although actual conflict over sex allocation is widespread, the conflict typically does not reach a worst-case scenario in which all colony resources are wasted in the conflict. As in all conflicts (Box S1), relatedness among colony members contributes to at least a partial resolution of sex-allocation conflict. However, relatedness costs only partially resolve sex-allocation conflict (105). The colonylevel cost the conflicting parties can tolerate depends upon the overall sex allocation ratio. At the two extremes of $50 \%$ and $75 \%$ female allocation, the nonoptimum party, whether queen or workers, can benefit if three units of allocation in the lessvaluable sex is traded for one unit of the more valuable. This favors ongoing conflict because the more the sex allocation ratio diverges from one party's optimum, the greater the incentive to manipulate the sex ratio and the greater the colony cost that can be tolerated in doing this $(96,105)$.

Coercion and constraint may help to resolve conflict if one party has complete power over sex allocation. Mixed power seems likely in many but not all situations. The queen plays her hand first via the eggs she lays, and in some taxa such as Pheidole ants, worker-queen caste determination begins in the egg stage under the influence of hormones sequestered there by the queen $(32,54)$. In that case, the queen may limit the number of queen-potentiated eggs $(32,54)$. The workers play second and can influence sex allocation by trading off queen rearing for worker $(32,48,87)$ or male rearing $(4,48,62,87,89,122)$.

Worker control is unlikely to completely resolve conflict because workers cannot affect the sex of the eggs laid by the queen. However, the colony cost to worker manipulation of the sex ratio may still be minimal if it results only in eggs or young larvae being killed. Research on Lasius niger ants has shown that young larvae are 
kept in piles according to sex and age, indicating that workers can determine their sex even as young larvae (58). However, in other species a lack of information may mean workers are unable to do so $(79,81,82)$. For example, in the wood ant F. exsecta, there is evidence that excess males are eaten late in larval development (23), although it is unclear if this is due to the inability of the workers to determine the sex of young larvae or because male larvae function as a food store or as a way of making it possible to increase total reproductive investment if food is abundant (23).

The conflict can be resolved if the queen has complete power. Lack of worker power is strongly suggested in slave-making ants, as brood rearing is carried out by allospecific slaves and allocation ratios are close to $50 \%$ female $(14,80,125)$. The queen can also gain power by producing either an exclusively male or exclusively female brood with equal probability $(54,86 a)$. This occurs in the ants Pheidole desertorum (54) and Solenopsis invicta (90) and prevents actual conflict, as in the male-specialist colonies the workers do not have the power to cause a femalebiased sex ratio because of a shortage of female eggs, and in the female-specialist colonies the queen and workers both agree on producing a female-biased sex ratio $(54,86 a)$. Consistent with this view, in P. desertorum, the population sex allocation ratio is close to $50 \%$ female, in line with the queen's optimum (54). In S. invicta, however, the population sex allocation ratio lies between the queen and worker optima, indicating that queen control is incomplete (90). Another strategy of queen control occurs in bumble bees. Here, the queen typically lays male eggs before female eggs (protandry) $(16,18 \mathrm{a})$. Such a temporal segregation in the rearing of males and queens reduces the opportunity for sex-ratio biasing and results in sex ratios that are close to even, in line with the queen's optimum $(16,18 \mathrm{a})$.

\section{QUEEN REARING}

\section{Basis for Conflict}

Potential conflict among the workers over queen rearing occurs when there are unequal degrees of relatedness from individual workers to different queens (47, $60,97,124,127)$. This occurs when the queen is mated to more than one male or when there is more than one mother queen. Hymenopteran colonies headed by a single queen mated to a single male $(12,115)$ or termite colonies headed by a single royal pair have no potential conflict over queen rearing. When multiple queens occur there is conflict between these queens over queen rearing (32).

\section{Is There Actual Conflict?}

Even though hymenopteran workers are related more to full-sisters $(r=0.75)$ than to half-sisters $(\mathrm{r}=0.25)$, there is little evidence that full-sisters are favored $(19,60,124,130)$. Possible nepotism in queen rearing has been looked for in the honey bee in all stages of queen rearing, from eggs and larvae (127) to young adult queens $(22,124)$, and the consensus is that it is weak or nonexistent (19). 
As with the honey bee, most studies of ant, wasp, or stingless bee societies headed by multiple queens have failed to find nepotism. Nepotistic interactions between workers and queens were not found in studies of the ants Formica argentea (114), Camponotus planatus (21), Camponotus yamaokai (111), Gnamptogenys striatula (7), or Leptothorax acervorum (53), the wasps Parachatergus colobopterus (118) or Polistes carolina (119), or the stingless bee Melipona bicolor (2). One exception is the wood ant Formica fusca, in which workers did preferentially rear more-related female larvae (50). The colonies used, however, were rearing only workers. Nepotism has been suggested to occur also in the polygynous termite Schedorhinotermes lamanianus, in which foraging columns tended to assort by kin (59).

\section{Conflict Resolution}

That nepotism in queen rearing is weak at best is at first surprising given the potential threefold advantage in inclusive fitness to a hymenopteran worker who rears full-sisters over half-sisters-the same advantage that a worker obtains from causing a female-biased sex ratio (see above). Kinship alone cannot explain the apparent absence of nepotistic queen rearing, especially as multiple paternity or multiple queens necessarily reduce kinship.

Nepotism may be rare because of errors in discriminating full-sisters from half-sisters $(60,97)$ (Box S2; follow the Supplemental Material link from the Annual Reviews home page at http://www.annualreviews.org). Recognition errors diminish or even eliminate any benefit of attempted nepotism (97). Empirical data suggest that recognition information may indeed be limiting. Workers of different patrilines in single-queen colonies of the ant Formica truncorum could not reliably be distinguished on the basis of cuticular hydrocarbons using coupled gas chromatography-mass spectroscopy (11). However, honey bee workers of different patrilines could be distinguished (3). Cuticular hydrocarbons from Polistinae and Vespinae wasps failed to distinguish reliably among patrilines but could distinguish among nestmate workers of different matrilines (30).

Theory shows reasons for information constraint (97). Discrimination requires considerable underlying genetic variation if full-sisters are to be recognized by being more similar to self than to half-sisters. However, the act of discrimination itself selects against rare recognition alleles, thereby reducing information and increasing errors (97). Other constraints may also be important. For example, full-sister versus half-sister recognition is more difficult if odors are mixed between individuals (e.g., among female ant larvae in a pile) or if within-colony cues are homogenized by selection for between-colony recognition (21). Finally, individuals may deliberately confuse or reduce the information they produce (60). For example, if workers identify more-related queens by possession of certain cues, queens benefit from producing all possible cues, thereby removing kin information. However, this would not work if workers identified queens by an exact matching. 


\section{MALE REARING}

\section{Basis for Conflict}

Male production is subject to great potential conflict in hymenopteran societies because workers can generally lay unfertilized male eggs (13). Usually, reproductive workers carry out little work and worker reproduction can reduce colony productivity, causing a "tragedy of the commons" $(51,136)$. The relatedness advantage of worker reproduction stems from haplodiploidy, which causes workers to be related less to brothers $(r=0.25)$ than to sons $(r=0.5)$ and enables them to lay male eggs even without the ability to mate or store sperm (24). (In a small number of species, workers can also produce female eggs parthenogenetically; see Reference 133.) Worker male production results in conflict with the mother queen, as she is related more to her own sons $(\mathrm{r}=0.5)$ than to workers' sons (grandsons, $\mathrm{r}=0.25$ ) (Figure 1). The queen, therefore, is selected to prevent workers from successfully reproducing ("queen policing") (95) (Figure 2d), and the workers are selected to replace the queen's sons. In annual societies, workers may gain control over male production by killing their mother queen (matricide) before the end of the colony cycle $(15,40)$. Worker reproduction can also involve conflict among workers, specifically between individual workers and the workers as a collective (95). For example, when the colony is headed by a multiply mated queen, workers are on average related more to the queen's sons (brothers, $r=0.25$ ) than to other workers' sons (full- and half-nephews, $r<0.25$ ) (95). In that case, workers are selected to prevent each other from reproducing ("worker policing") (95).

\section{Is There Actual Conflict?}

Potential conflict over male parentage is almost universal. In only seven genera of ants, Atta, Linepithema, Monomorium, Pheidole, Pheidologeton, Tetramorium, and Solenopsis (86), and three genera of stingless bees, Duckeola, Frieseomelitta, and Tetragonula (29), are workers fully sterile by lacking functional ovaries, thereby resolving male-rearing conflict. In other species, actual conflict over male parentage is frequently observed. In a forthcoming study of eight species of wasps, for example, between $1 \%$ and $20 \%$ of the workers in colonies with a queen had active ovaries, and between $31 \%$ and $81 \%$ of the male eggs were laid by workers (T. Wenseleers \& F. L. W. Ratnieks, manuscript submitted). Selective policing of worker-laid eggs $(40,95,132,134,136,143)$, however, frequently reduces the rearing of workers' sons (49). In the honey bee, $7 \%$ of the male eggs are laid by workers (129), but only 1 adult male per 1,000 is a worker's son (128). The degree of actual conflict varies greatly. In an analysis of 90 species, the proportion of males that were workers' sons averaged at $12 \%$ and ranged from $0 \%$ to $100 \%$ (49, 139). Matricide has been found in annual societies of Vespidae wasps $(15,40)$ and bumble bees (15). In these and other species, the death of the queen results in widespread worker production of males (13). 


\section{Conflict Resolution}

Two main factors affect the resolution of conflict over male rearing: relatedness and coercion of workers in the form of the policing of their eggs (Figure 2). The effect of relatedness can work in two opposite directions. In the absence of policing, high relatedness favors fewer workers to lay eggs $(13,136)$. Although this may help to resolve conflict, the effect is limited because, even with high relatedness, many of the workers are selected to lay eggs (14\% to 54\% with paternity frequencies ranging from 1 to 10) (136) (Box S1). Evidence that lower relatedness leads to more worker reproduction occurs in two bumble bees, Bombus terrestris and $B$. occidentalis, in which workers that have entered unrelated colonies are more likely to reproduce $(6 \mathrm{a}, 68)$.

Conversely, as discussed above, low relatedness caused by multiple paternity can also help to resolve conflict by favoring worker policing (95). Several lines of evidence support this prediction. First, worker policing has been discovered in three species of Apis honey bees $(46,85,101)$ (Figure $2 a$ ) and the common wasp Vespula vulgaris (39), in which queens are multiply mated (115). Second, in the saxon wasp Dolichovespula saxonica, genetic analysis indicates that worker policing occurs in colonies with a multiply mated queen, but not in those headed by a singly mated one (38) (Figure $2 b$ ). Finally, a comparative analysis of male parentage across 90 species of social Hymenoptera showed that significantly fewer males were workers' sons when workers were related more to the queen's sons (139) (Figure 4). In 75 species in which workers were more related to workers' sons, an average of $14 \%$ of the males were workers' sons. By contrast, in 15 species in which workers were related more to the queen's sons, an average of only $0.2 \%$ of the males were workers' sons (Figure 4). This strongly suggests that worker policing was favored on relatedness grounds. A previous study (49) did not find this trend but was based on a smaller data set. Further evidence that low relatedness reduces queen-worker conflict over male production comes from data showing that queen loss (matricide) is more frequent in Vespinae wasp species in which queens are predominantly singly mated (40). In addition, matricide occurs in bumble bees (15), which typically have singly mated queens $(12,115)$.

Recent research indicates that worker policing may be widespread, as it occurs in 29 species (Table S1; follow the Supplemental Material link from the Annual Reviews home page at http://www.annualreviews.org). Interestingly, some of these species have queens that typically mate only once, for example, the ant Camponotus floridanus (33) (Figure 2c) and the hornet Vespa crabro (37). However, in such species worker policing can also be favored if the killing of worker-laid eggs helps the workers cause a more female-biased sex allocation ratio (41), if it increases total colony reproduction (95), or if it gives policing workers a greater opportunity to reproduce directly ("selfish" policing) $(110,143)$. Hence, many factors can select for worker policing and may together help to resolve conflict.

There is also abundant evidence that the queen may police worker-laid eggs or aggress egg-laying workers (Table S1). Queen policing is known to occur in 
36 species (Table $\mathrm{S} 1$ ) and is particularly common in small-colony species, including Halictidae bees (73), bumble bees (43), and small-colony Polistine and Vespinae wasps $(110,132,143)$ (Table S1). Another queen strategy may be to mark her eggs with pheromone in order to facilitate worker policing (95). Consistent chemical differences between queen-laid and worker-laid eggs have indeed been found in both the honey bee, Apis mellifera, and the ant $C$. floridanus $(33,70)$.

Both queen and worker policing have several consequences for conflict resolution. First, they reduce the proportion of workers' sons that are reared. Here, worker policing is typically more effective than queen policing, because it is harder for the queen to control the whole colony (95). For example, in the honey bee, worker policing is $98 \%$ effective and results in only $0.1 \%$ of the adult males being workers' sons (129). In contrast, in three wasp species, Polistes chinensis, Vespula rufa, and Dolichovespula sylvestris, queen policing only results in the killing of $69 \%, 39 \%$, and $27 \%$ of the eggs laid by workers $(110,132,143)$. A second effect of policing is that it reduces the benefit for workers to lay eggs in the first place. Theory shows that this favors worker self-restraint $(134,136)$. In a forthcoming study of nine species (eight Vespidae wasps and the honey bee) we show that this prediction is supported: Fewer workers attempt to reproduce in species in which policing is more effective (T. Wenseleers \& F. L. W. Ratnieks, manuscript submitted) (Figure 5). This preventive effect of policing can result in a highly effective conflict resolution. For example, in the absence of policing, theory predicts that $54 \%$ of the worker honey bees in a colony with a queen would be selected to reproduce (Box S1). However, effective policing reduces the benefit of worker reproduction to such an extent that, in fact, only around $0.1 \%$ of the honey bee workers activate their ovaries. The vast majority work to make the colony more productive (98). Even with effective policing, however, potential conflict over male production does not disappear, as there is selection on individual egg-laying workers to evade policing. Evidence for this comes from the discovery of anarchistic and parasitic Cape honey bee workers that lay eggs which evade policing, presumably by chemically mimicking those of the queen $(5,69)$ (Figure $3 a, b)$. Nevertheless, anarchistic colonies are rare, possibly because the genetics of anarchy depends on multiple genetic loci, each with a cost (5).

\section{CASTE FATE CONFLICT}

\section{Basis for Conflict}

Perhaps the outstanding characteristic of eusocial insects is the presence of morphologically distinct reproductive and worker castes (144). Workers are less fecund and are unable to mate or found a colony. This inequality leads to potential conflict because each individual obtains greater inclusive fitness by developing as a queen (or king) rather than as a worker $(18,106,140)$ (Box S1). Theory predicts that individuals should attempt to become reproductives even if this causes fewer 


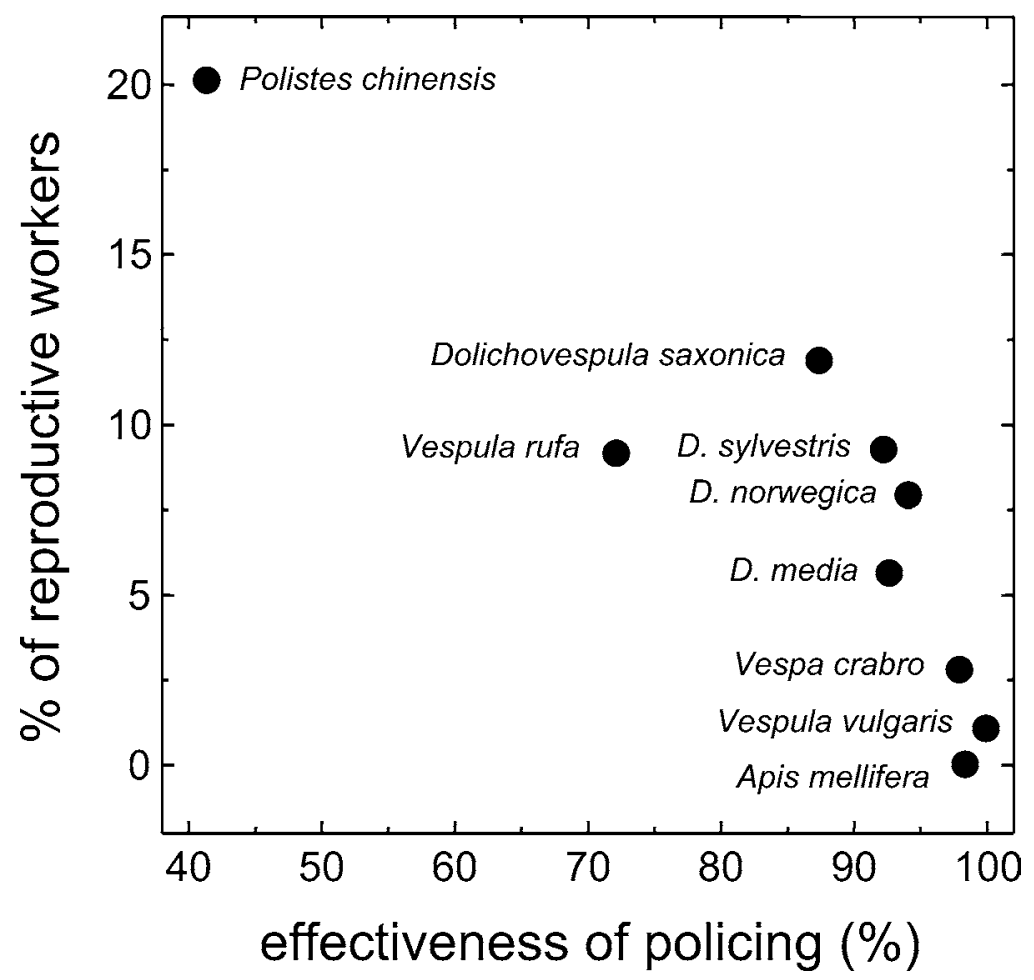

Figure 5 More effective policing results in fewer workers attempting to reproduce, as shown by this comparative data set of eight Vespidae wasps and the honey bee, Apis mellifera (T. Wenseleers \& F. L. W. Ratnieks, manuscript submitted). This observed trend closely matches theoretical predictions $(134,136)$.

workers to be reared, thereby reducing colony productivity $(99,106,140)$ (Box S1) (Figure 6). As in the conflict over male rearing, this may create a tragedy of the commons (51), in which individual selfishness is costly to all $(138,140)$. However, even while selected to be selfish themselves, each colony member also benefits from attempting to coerce others to become workers, thereby preventing an overproduction of reproductives (140).

\section{Is There Actual Conflict?}

Potential conflict over caste fate is almost universal in insect societies. However, actual conflict is relatively rare and restricted to species in which immature individuals can determine their own caste fate $(6,18,140)$ (Figure 6). In Melipona bees, female larvae can determine their own caste fate because queens and workers are the same size and are reared in identical, sealed cells $(34,63)$. In line with 


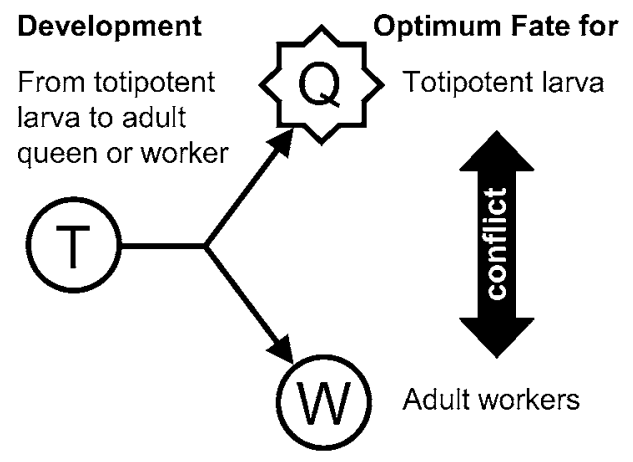

Factors Influencing Power

Small Q-W size difference

Sealed cells

Larva can obtain more food

Large $\mathrm{Q}-\mathrm{W}$ size difference

Open cells

Larva can't obtain more food

Figure 6 The logic of caste fate conflict. When a colony is rearing both queens and workers at the same time, a female larva is better off to be reared as a queen. However, the adult workers will normally benefit if fewer larvae develop into queens than is optimal for the larvae themselves. Several factors influence the balance of power between larvae and adults.

prediction, a large percentage ( $5 \%$ to $25 \%$ ) of the females develop into queens $(63,77 \mathrm{a}, 138)$ (Figure $3 e)$, a vast overproduction given that only a few queens are needed for reproduction by swarming. Excess queens are killed by the workers soon after they emerge from their cells $(64,135)$ (Figure $3 f$ ). Similar evidence for actual conflict occurs in the lower termite families Kalotermitidae and Termopsidae, in which nymphs can control their own caste development because they feed directly from the wood that lines the inside of their nest cavity (131). Upon loss of the royal pair, a great excess of workers (who are immature instars) molt into replacement reproductives $(78,140)$. For example, in Cryptotermes domesticus and Kalotermes flavicollis, up to $58 \%$ and $42 \%$ of all nymphs molt into replacement reproductives, even though only a single pair (male and female) is needed. Same-sex fighting among the reproductives then ensues until only a single member of each sex remains (78) (Figure $3 h$ ).

In most other social Hymenoptera and in the advanced termites, actual caste fate conflict does not occur because larvae cannot determine their own caste fate. Instead, workers determine the caste fate of larvae by different feeding regimes, and queens or reproductives are produced in proportion to colony needs $(18,140$, 144) (Figures 6 and 7). Swarm-founding species such as honey bees, trigonine stingless bees, and army ants, for example, generally rear queens sparingly (18, 140). Honey bee colonies typically produce only approximately 10 to 25 queens, in preparation for swarming or to supersede a failing mother queen, but may produce 150,000 workers per year (145) (Figure 2e). Similarly, in the trigonine stingless bees Tetragonisca angustula and Trigona ventralis, only $0.02 \%$ (126) and $0.08 \%$ (25) of the females are reared as queens, and in the army ant, Eciton burchelli, only about 1 queen is reared per 50,000 workers (112). 


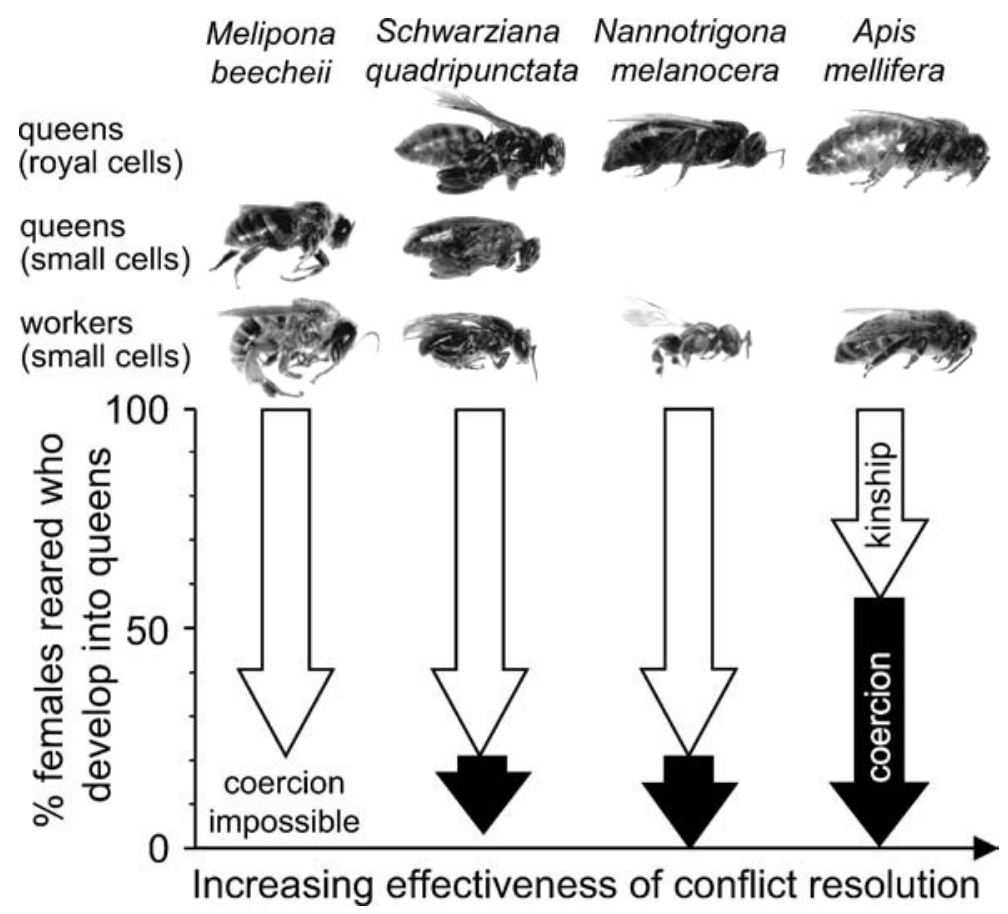

Figure 7 The roles of kinship and coercion in resolving caste fate conflict. In four species of bees that found colonies by swarms, the worst-case scenario is that all female larvae develop into queens. Kinship alone is sufficient to diminish the proportion that should develop into queens to $\sim 20 \%$ in the three species of stingless bees (M. beecheii, S. quadripunctata, and N. melanocera) and to $54 \%$ in the honey bee, A. mellifera. Kinship is less effective in conflict resolution in honey bees, as multiple mating by the queen leads to lower relatedness among female offspring $(r=0.3)$ than in the stingless bees $(\mathrm{r}=0.75)$, in which queens mate with a single male. In A. mellifera and $N$. melanocera, the workers fully coerce the female larvae by the use of specialized worker (small) and queen (large) cells so that feeding control can prevent excess queens from being reared. In $S$. quadripunctata, feeding control is not fully effective, as some of the larvae reared in small cells develop into dwarf queens instead of workers. In $M$. beecheii, all larvae are reared in the same-sized cells. Coercion by food control is not possible and many excess queens are reared.

Caste fate conflict is most easily seen in swarm-founding species, because very few queens are required to swarm effectively and excess queens are killed (140). Actual caste fate conflict may also occur in species in which queens found nests without workers (106). However, it is much harder to demonstrate (108) because independently founding species typically rear many queens and would not be selected to kill excess queens once reared. 


\section{Conflict Resolution}

Two major factors contribute to the resolution of caste fate conflict: relatedness and whether larvae can be coerced to become workers. High relatedness reduces the incentive for individual selfishness and therefore lowers the proportion of larvae that is selected to become reproductives (Figure 1) (Box S1). This prediction is supported by a comparison of queen production in four Melipona species in which kinship patterns differed as a result of variable male production by workers (138). Increased male production by workers raised the relatedness between female larvae and the males reared and was associated with a decreased proportion of larvae developing into queens, as predicted (138). Relatedness also affects caste fate conflict in the social gall aphid Pemphigus obesinymphae (1) (Figure 3g). Aphids from other clones frequently invade galls. These intruders behave selfishly and parasitize the unrelated host aphids by accelerating their own development into reproductive stages rather than defensive stages. Similarly, nearly all female larvae of permanently parasitic ants develop as miniature queens. Here, the cost of acting selfishly again falls on members of the unrelated host's workforce (83).

In the above examples there is great actual conflict, and relatedness can only partially resolve caste fate conflict (Figure 1). A more complete resolution, however, occurs when larvae are constrained from determining their own caste fate (Figures 6 and 7). In most social Hymenoptera, including the honey bees, trigonine stingless bees, and army ants discussed above, queens are much larger than workers and caste is determined by nutrition $(18,140,144)$. Hence, adult workers can coerce immature females to become workers simply by providing them with insufficient food, thus preventing their development into queens $(18,102,140)$. Similarly, larvae are constrained because they cannot leave their cells or brood piles in search of additional food, and only in some species can they obtain extra food through begging $(25 a, 59 a)$. The result is that few queens are reared in these species, and that caste fate conflict is effectively resolved $(25,112,126,145)$. In the honey bee, only $0.02 \%$ of the female brood are reared as queens (145). This low level is remarkable given that theory has shown that, from an individual perspective, approximately $56 \%$ of all female honey bee larvae would prefer to develop as queens if they could choose their own fate (Box S1) (Figure 7). Social control over caste fate is also likely in advanced termites such as the Termitidae, given that immature forms are fed by workers and that workers differentiate irreversibly early on in their development (131). As predicted, they never overproduce reproductives (78). In some lower termites, a process of wing pad mutilation has been suggested to prevent workers from developing into alate sexuals (147). However, the evidence for this has recently been disputed (64a).

Although adult workers benefit from coercing immatures to develop as workers, there is also selection on developing individuals to evade such coercion. Evidence for such evasion has been found in several taxa $(18,102,140,141)$. In the trigonine stingless bees, for example, queens are typically reared from larger royal cells (34). However, in some species, including Schwarziana quadripunctata (141) 
(Figure 7), females reared in small cells can evade their intended worker fate and become "dwarf" queens (141) (Figure 3c,d). Although dwarf queens can successfully head colonies, they may have lower fecundity than normal queens and are sometimes eliminated by the workers $(102,141)$. This reduces the benefit of this reproductive strategy (134) and explains why in Schwarziana bees only $0.6 \%$ of the females reared in worker cells develop into dwarf queens (141). Small microgyne or wingless intermorphic queens are also occasionally produced in some ants $(18,52,108)$, and in two species, Harpagoxenus sublaevis and Leptothorax sp. A, their production is under individual genetic rather than environmental control (52). This demonstrates a degree of self-determination and suggests that caste fate conflict may underlie their production. Queen miniaturization also allows parasitic ants who enter colonies of other species to develop as queens even when reared on an amount of food that is meant to produce only workers in the host (83). Finally, another strategy to evade coercion occurs in two genera of stingless bees, Leurotrigona and Frieseomelitta. Here, female larvae can selfishly develop as queens by consuming the food provision of a neighboring cell (34). These examples illustrate that, although caste fate conflict is typically well resolved, traces of conflict can be found.

\section{CONFLICTS AMONG TOTIPOTENT INDIVIDUALS}

\section{Basis for Conflict}

In many social Hymenoptera, including Polistinae and Stenogastrinae wasps and Halictidae and Allodapini bees, queen-worker dimorphism is either weak or absent $(84,120,144)$. In these, all or most females are "totipotent," i.e., they have the ability to mate and produce both male and female offspring. Totipotency also occurs in approximately 100 species of Ponerinae ants that have secondarily lost the queen caste and that have colonies headed by one or more mated workers ("gamergates") (76). Totipotency greatly increases the potential for conflict, as it allows any individual in the colony to replace the existing queen $(76,77)$, to become an additional queen (67), or, except in Ponerinae ants and epiponine Polistinae wasps, to found a nest independently (103). The relatedness benefits for females to mate and breed are similar to those of becoming a morphologically specialized queen (see above). That is, in the face of reproductive competition with sisters, a female benefits if she becomes a breeder and produces offspring (sons and daughters, $r=0.5$ ) rather than a worker rearing the less-related offspring of sisters (nephews and nieces, $r=0.375)(76,77)$. Actual conflict can result in an excess of females attempting to mate and breed (67), in females attempting to overthrow the existing queen $(76,77)$, or, in annual societies, in females leaving the colony early in order to enter diapause to found a colony the next year $(104,116,146)$.

\section{Is There Actual Conflict?}

There is extensive evidence for actual conflict over reproduction in societies of totipotent females. In polygynous swarm-founding epiponine wasps, an excess of 
females mate to be readopted in the natal nest when colonies have few mother queens left $(55,94,120)$. The excess then reduces via queen-queen competition or active elimination by workers (92). Evidence of excess individuals attempting to mate and breed comes from the queenless ponerine ants Harpegnathos saltator (67) and Gnamptogenys menadensis $(44,76)$. Attempts by high-ranking workers (hopeful reproductives) to overthrow the existing breeder have been observed in the queenless ant Dinoponera quadriceps $(74,77)$. Evidence that females in annual societies leave the colony early to become a queen the next year comes from the sweat bee Halictus rubicundus (146) and the paper wasps Polistes annularis (116) and Polistes fuscatus (104).

\section{Conflict Resolution}

Both relatedness and coercion can resolve conflict in totipotent societies. Relatedness is important in that it reduces potential conflict. For example, theory predicts that higher relatedness reduces the incentive for individuals to join a hierarchy of nonworking hopeful reproductives (75) or, in annual societies, to leave the colony early (104). Relatedness alone, however, is only partially effective. In the queenless ant $D$. quadriceps, an inclusive fitness model predicted that about five workers should join a hierarchy of dominants if they are nieces of each other $(\mathrm{r}=0.375)$ but that only four should do so if they are full-sisters $(\mathrm{r}=0.75)(74)$. Hence, although relatedness diminishes the conflict, it does not reduce it down to zero.

More effective conflict resolution occurs if individuals can be coerced not to breed. Such coercion can take on various forms. In D. quadriceps ants, workers cannot be prevented from joining a dominance hierarchy. However, the beta worker frequently challenges the alpha (the mated breeding female) and attempts to overthrow her in the hope of heading the colony (77). Such overthrow is prevented by a form of policing (77). If the beta challenges the alpha, the alpha smears the pretender with a pheromone (77). This induces low-ranking workers to punish the pretender by immobilizing her for a prolonged period that kills her or causes her to lose her high rank and thereby prevents her from legitimately replacing the alpha at a later date (Figure $2 g$ ).

A similar and idiosyncratic form of coercion occurs in the queenless ant Diacamma $(91)$ (Figure $2 h$ ). Here, all workers eclose with a pair of thoracic appendages called gemmae that are somehow required for mating $(76,91)$. However, unless a new breeder is needed, the gemmae of newly eclosed workers are bitten off by nestmates so that no worker gets a chance to breed unless the colony requires it (76, 91). In two other queenless ants, $H$. saltator and G. menadensis, immobilization also occurs $(44,67)$ but prevents the colony, which typically has several queens, from acquiring too many breeders (Figure $2 f$ ).

Evidence that females are aggressively prevented from mating also exists (20, 45). In the allodapine bee Exoneura robusta, dominant mothers can prevent females from mating by rejecting those that have been in contact with foreign males (20). In annual societies, however, such a mechanism may only be partially effective, as 
it cannot prevent females from breeding by leaving the nest completely to become a queen the next year $(104,116,146)$.

Another form of coercion in conflicts among totipotent individuals is social contracts, which are thought to be important in favoring the cofounding of nests when there is inequality among the foundresses (103). Dominants, it is argued, should offer a sufficiently large reproductive share to the subordinate, lest the subordinate would leave to found her own nest (103). There is currently little evidence, however, that social contracts are used in social insects $(27,35)$. Recent data from the allodapine bee Exoneura nigrescens, for example, were more consistent with reproductive shares arising from selfish competition (66).

\section{DISCUSSION AND CONCLUSION}

A major factor in conflict resolution is kinship, with greater relatedness decreasing the incentive for selfishness. Thus, even when female larvae can choose their own caste fate, they are not all selected to become queens (Box S1). Similarly, even if worker-laid eggs are not policed, not all workers should lay eggs instead of working. In a colony with a single, once-mated queen, approximately $14 \%$ to $20 \%$ of female brood are expect to become excess queens and a similar proportion of workers are expected to lay eggs (Box S1). Societies with these proportions exist, such as Melipona bees and Polistes chinensis wasps, and are successful, showing that insect colonies can function even under these levels of conflict (36).

Nevertheless, most conflicts are reduced to even lower levels. The honey bee is a clear example. Multiple mating by the queen results in low relatedness among the female offspring, and kinship alone favors approximately half the female larvae to develop into queens or to lay eggs rather than work (Box S1). Yet honey bee colonies do not rear excess queens as do Melipona, and less than $0.1 \%$ of the workers have active ovaries. The very effective resolution of these conflicts is due to coercion and constraints. Larvae are constrained from developing into queens unless given special additional food by the workers. Adult workers are constrained from producing males because of effective policing of worker-laid eggs (Figure 2). Multiple mating by the queen also reduces potential worker-queen conflict over sex allocation, as it results in a close alignment of the queen and worker optima. Multiple mating does cause potential conflict over queen rearing, but extensive research over the past 20 years has failed to find evidence of strong nepotism in queen rearing. Thus, of the three significant potential conflicts that exist, two (male rearing and female caste fate) have been resolved largely by coercion combined with constraint and one (queen rearing) probably through informational constraints.

There are important differences among the various conflicts in if and how they are resolved. Conflict over queen rearing could be called the conflict that does not occur, inasmuch as there is little evidence for actual conflict despite strong potential conflict in species with multiple queens or a multiply mated queen. Caste fate conflict is the conflict that is almost always resolved, because workers 
can usually police the caste development of female larvae. However, the rearing of excess queens in Melipona bees and dwarf queens in S. quadripunctata and other stingless bees, and possibly also in ants, shows that the conflict does exist and can become actual when circumstances allow larvae power to choose their own fate. Male production is a conflict that is frequently resolved, such that very few workers lay eggs, but significant male production by workers occurs in many species. Resolution of this conflict depends on policing by the queen and by other workers. Sex-allocation conflict is often unresolved, with both queen and workers typically having some power to manipulate colony sex ratios. Only when one party is powerless is the conflict resolved, with the sex ratio favoring that of the controlling party. Conflicts are perhaps least resolved in societies with totipotent individuals, in which the incentives and opportunities to compete over reproduction are greatest.

The large body of theoretical and empirical work has provided a good overall understanding of the expression and resolution of conflicts in insect societies. This work has been central to our current understanding of kin selection theory $(17,28$, $40,61,139)$. Future work will no doubt discover interesting new conflict outcomes and resolutions, and a number of exciting new research directions are emerging. For example, only recently has it been established that conflict resolution via coercion can lead to counter-strategies, as in the anarchistic and parasitic honey bees $(5,69)$ and dwarf queens in stingless bees (141), where individuals have found ways to escape social control. Other such strategies may well be discovered in the future. On the theoretical side, models are increasingly considering the subtle ways in which different conflicts may interact or arms races may proceed $(41,105,106)$. Empirically, we still need a better understanding of the information used in the recognition decisions central to manipulation of colony reproduction (Box S2). Studies have begun to analyze the chemicals present in insect colonies, but the challenge is to develop elegant bioassays that identify biologically active compounds. Finally, we know almost nothing of the genes affecting conflict in social insects (but see Reference 65 for an exception). Research on microorganisms shows that genetics can play a role in conflict resolution (42) and that the multilocus genetics of the syndrome may help select against anarchy in honey bees (5). Recent genetic studies have also suggested that intragenomic conflicts could interact with the expression of intracolony conflict $(137,142)$, and this would certainly be an interesting avenue for future research. Finally, progress is being made on genome sequencing and transcriptional profiling, and RNA interference has now been performed on the honey bee (107). This work should ultimately provide a new perspective on conflict resolution by allowing researchers to identify genes involved in conflict and compare them across species.

\section{ACKNOWLEDGMENTS}

We wish to thank V.-L. Imperatriz-Fonseca and J.J.G. Quezada-Euán for providing material for photography; J.M.F. Camargo, J.I. Cuadriello-Aguilar, J. Korb, J. Liebig, S.J. Martin, T. Monnin, N.A. Moran, and B.P. Oldroyd for providing photos; 
and J.J. Boomsma and A.F.G. Bourke for comments. This work was supported by fellowships from the Wissenschaftskolleg zu Berlin to FLWR, KRF, and TW.

\section{The Annual Review of Entomology is online at http://ento.annualreviews.org}

\section{LITERATURE CITED}

1. Abbot P, Withgott JH, Moran NA. 2001. Genetic conflict and conditional altruism in social aphid colonies. Proc. Natl. Acad. Sci. USA 98:12068-71

2. Alonso WJ, Lucena T, Fracasso CM, Velthuis HHW, Imperatriz-Fonseca VL. 1998. Do Melipona bicolor (Apidae, Meliponinae) workers distinguish relatedness among different physogastric queens? Apidologie 29:503-12

3. Arnold G, Quenet B, Comuet J-M, Masson C, de Scheper B, et al. 1996. Kin recognition in honeybees. Nature 379:498

4. Aron S, Vargo EL, Passera L. 1995. Primary and in honey-bees (Apis) and the anarchic syndrome: a review. Behav. Ecol. Sociobiol. 50:199-208

5. Barron AB, Oldroyd BP, Ratnieks FLW. 2001. Worker reproduction in honey-bees (Apis) and the anarchic syndrome: a review. Behav. Ecol. Sociobiol. 50:199-208

6. Beekman M, Ratnieks FLW. 2003. Power over reproduction in social Hymenoptera. Philos. Trans. R. Soc. London B Biol. Sci. 358:1741-53

6a. Birmingham AL, Hoover SE, Winston ML, Ydenberg RC. 2004. Drifting bumble bee (Hymenoptera: Apidae) workers in commercial greenhouses may be social parasites. Can. J. Zool. 82:1843-53

7. Blatrix R, Durand JL, Jaisson P. 2000. Task allocation depends on matriline in the ponerine ant Gnamptogenys striatula Mayr. J. Insect Behav. 13:553-62

8. Boomsma JJ. 1989. Sex-investment ratios in ants: Has female bias been systematically overestimated? Am. Nat. 133:51732

9. Boomsma JJ, Baer B, Heinze J. 2005. The evolution of male traits in social insects. Annu. Rev. Entomol. 50:395-420

10. Boomsma JJ, Grafen A. 1991. Colony level sex ratio selection in the eusocial Hymenoptera. J. Evol. Biol. 4:383-407

11. Boomsma JJ, Nielsen J, Sundström L, Oldham NJ, Tentschert J, et al. 2003. Informational constraints on optimal sex allocation in ants. Proc. Natl. Acad. Sci. USA 100:8799-804

12. Boomsma JJ, Ratnieks FLW. 1996. Paternity in eusocial Hymenoptera. Philos. Trans. R. Soc. London B Biol. Sci. 351:947-75

13. Bourke AFG. 1988. Worker reproduction in the higher eusocial Hymenoptera. $Q$. Rev. Biol. 63:291-311

14. Bourke AFG. 1989. Comparative analysis of sex-investment ratios in slave-making ants. Evolution 43:913-18

15. Bourke AFG. 1994. Worker matricide in social bees and wasps. J. Theor. Biol. 167:283-92

16. Bourke AFG. 1997. Sex ratios in bumble bees. Philos. Trans. R. Soc. London B Biol. Sci. 352:1921-32

16a. Bourke AFG. 2005. Genetics, relatedness and social behaviour in insect societies. In Insect Evolutionary Ecology, ed. MDE Fellowes, GJ Holloway, J Rolff, pp. 1-30. Wallingford: CABI

17. Bourke AFG, Franks NR. 1995. Social Evolution in Ants. Princeton, NJ: Princeton Univ. Press. 529 pp.

18. Bourke AFG, Ratnieks FLW. 1999. Kin conflict over caste determination in social Hymenoptera. Behav. Ecol. Sociobiol. 46:287-97

18a. Bourke AFG, Ratnieks FLW. 2001. Kin-selected conflict in the bumble-bee 
Bombus terrestris (Hymenoptera: Apidae). Proc. R. Soc. London B Biol. Sci. 268:347-55

19. Breed MD, Welch CK, Cruz R. 1994. Kin discrimination within honey bee (Apis mellifera) colonies: an analysis of the evidence. Behav. Process. 33:24-40

20. Bull NJ, Mibus AC, Norimatsu Y, Jarmyn BL, Schwarz MP. 1998. Giving your daughters the edge: bequeathing reproductive dominance in a primitively social bee. Proc. R. Soc. London B Biol. Sci. 265:1411-15

21. Carlin NF, Reeve HK, Cover SP. 1993. Kin discrimination and division of labor among matrilines in the polygynous carpenter ants, Camponotus platanus. In Queen Number and Sociality in Insects, ed. L Keller, pp. 362-401. Oxford, UK: Oxford Univ. Press

22. Châline N, Martin SJ, Ratnieks FLW. 2005. Absence of nepotism toward imprisoned young queens during swarming in the honey bee. Behav. Ecol. 16:403-9

23. Chapuisat M, Sundström L, Keller L. 1997. Sex-ratio regulation: the economics of fratricide in ants. Proc. R. Soc. London B Biol. Sci. 264:1255-60

24. Charnov EL. 1978. Evolution of eusocial behavior: offspring choice or parental parasitism? J. Theor. Biol. 75:451-65

25. Chinh TX, Sommeijer MJ. 2005. Production of sexuals in the stingless bee Trigona (Lepidotrigona) ventralis flavibasis Cockerell (Apidae, Meliponini) in northern Vietnam. Apidologie 36:493-503

25a. Creemers B, Billen J, Gobin B. 2003. Larval begging behaviour in the ant Myrmica rubra. Ethol. Ecol. Evol. 3:261-72

26. Cremer S, Sledge MF, Heinze J. 2002. Male ants disguised by the queen's bouquet. Nature 419:897

27. Crespi BJ, Ragsdale JE. 2000. A skew model for the evolution of sociality via manipulation: why it is better to be feared than loved. Proc. R. Soc. London B Biol. Sci. 267:821-28

28. Crozier RH, Pamilo P. 1996. Evolution of Social Insect Colonies: Sex Allocation and Kin Selection. Oxford, UK: Oxford Univ. Press

29. Cruz-Landim C. 2000. Ovarian development in meliponine bees (Hymenoptera: Apidae): the effect of queen presence and food on worker ovary development and egg production. Genet. Mol. Biol. 23:8388

30. Dani FR, Foster KR, Zacchi F, Seppa P, Massolo A, et al. 2004. Can cuticular lipids provide sufficient information for within-colony nepotism in wasps? Proc. R. Soc. London B Biol. Sci. 271:745-53

31. Dawkins R. 1976. The Selfish Gene. Oxford, UK: Oxford Univ. Press. $224 \mathrm{pp}$.

32. de Menten L, Fournier D, Brent C, Passera L, Vargo EL, et al. 2005. Dual mechanism of queen control over sex ratio in the ant Pheidole pallidula. Behav. Ecol. Sociobiol. In press

32a. Duchateau MJ, Velthuis HHW, Boomsma JJ. 2004. Sex ratio variation in the bumblebee Bombus terrestris. Behav. Ecol. 15:71-82

33. Endler A, Liebig J, Schmitt T, Parker JE, Jones GR, et al. 2004. Surface hydrocarbons of queen eggs regulate worker reproduction in a social insect. Proc. Natl. Acad. Sci. USA 101:2945-50

34. Engels W, Imperatriz-Fonseca VL. 1990. Caste development, reproductive strategies, and control of fertility in honey bees and stingless bees. In Social Insects: An Evolutionary Approach to Castes and Reproduction, ed. W Engels, pp. 167-230. Berlin/Heidelberg: Springer-Verlag

35. Field J, Solis CR, Queller DC, Strassmann JE. 1998. Social and genetic structure of paper wasp cofoundress associations: tests of reproductive skew models. Am. Nat. 151:545-63

36. Foster KR. 2004. Diminishing returns in social evolution: the not-so-tragic commons. J. Evol. Biol. 17:1058-72

37. Foster KR, Gulliver J, Ratnieks FLW. 2002. Worker policing in the European 
hornet Vespa crabro. Insectes Soc. 49:4144

38. Foster KR, Ratnieks FLW. 2000. Facultative worker policing in a wasp. Nature 407:692-93

39. Foster KR, Ratnieks FLW. 2001. Convergent evolution of worker policing by egg eating in the honeybee and common wasp. Proc. R. Soc. London B Biol. Sci. 268:169-74

40. Foster KR, Ratnieks FLW. 2001. Paternity, reproduction and conflict in vespine wasps: a model system for testing kin selection predictions. Behav. Ecol. Sociobiol. 50:1-8

41. Foster KR, Ratnieks FLW. 2001. The effect of sex-allocation biasing on the evolution of worker policing in hymenopteran societies. Am. Nat. 158:615-23

42. Foster KR, Shaulsky G, Strassmann JE, Queller DC, Thompson CRL. 2004. Pleiotropy as a mechanism to stabilize cooperation. Nature 431:693-96

42a. Foster KR, Wenseleers T, Ratnieks FLW. 2001. Spite: Hamilton's unproven theory. Ann. Zool. Fenn. 38:229-38

43. Free JB, Weinberg I, Whiten A. 1969. The egg-eating behaviour of Bombus lapidarius L. Behaviour 35:313-17

44. Gobin B, Billen J, Peeters C. 1999. Policing behaviour towards virgin egg layers in a polygynous ponerine ant. Anim. Behav. 58:1117-22

45. Greenberg L, Buckle GR. 1981. Inhibition of worker mating by queens in a sweat bee, Lasioglossum zephyrum. Insectes Soc. 28:347-52

46. Halling LA, Oldroyd BP, Wattanachaiyingcharoen $\mathrm{W}$, Barron $\mathrm{AB}$, Nanork $\mathrm{P}$, et al. 2001. Worker policing in the bee Apis florea. Behav. Ecol. Sociobiol. 49:50913

47. Hamilton WD. 1964. The genetical evolution of social behaviour. I and II. J. Theor. Biol. 7:1-52

48. Hammond RL, Bruford MW, Bourke AFG. 2002. Ant workers selfishly bias sex ratios by manipulating female develop- ment. Proc. R. Soc. London B Biol. Sci. 269:173-78

49. Hammond RL, Keller L. 2004. Conflict over male parentage in social insects. PLoS Biol. 2:1-11

50. Hannonen M, Sundström L. 2003. Worker nepotism among polygynous ants. Nature 421:910

51. Hardin G. 1968. The tragedy of the commons. Science 162:1243-44

52. Heinze J. 1998. Intercastes, intermorphs, and ergatoid queens: Who is who in ant reproduction? Insectes Soc. 45:113-24

53. Heinze J, Elsishans C, Hölldobler B. 1997. No evidence for kin assortment during colony propagation in a polygynous ant. Naturwissenschaften 84:249-50

54. Helms KR. 1999. Colony sex ratios, conflict between queens and workers, and apparent queen control in the ant Pheidole desertorum. Evolution 53:1470-78

55. Henshaw MT, Strassmann JE, Queller DC. 2000. The independent origin of a queen number bottleneck that promotes cooperation in the African swarmfounding wasp, Polybioides tabidus. Behav. Ecol. Sociobiol. 48:478-83

56. Hölldobler B, Wilson EO. 1990. The Ants. Berlin/Heidelberg: Springer-Verlag

57. Hurst LD, Atlan A, Bengtsson BO. 1996. Genetic conflicts. Q. Rev. Biol. 71:31764

58. Jemielity S, Keller L. 2003. Queen control over reproductive decisions: no sexual deception in the ant Lasius niger. Mol. Ecol. 12:1589-97

59. Kaib M, Husseneder C, Epplen C, Epplen JT, Brandl R. 1996. Kin-biased foraging in a termite. Proc. R. Soc. London B Biol. Sci. 263:1527-32

59a. Kaptein N, Billen J, Gobin B. 2005. Larval begging for food enhances reproductive options in the ponerine ant Gnamptogenys striatula. Anim. Behav. 69:293-99

60. Keller L. 1997. Indiscriminate altruism: unduly nice parents and siblings. Trends Ecol. Evol. 12:99-103

61. Keller L, ed. 1999. Levels of Selection in 
Evolution. Princeton, NJ: Princeton Univ. Press. 313 pp.

62. Keller L, Aron S, Passera L. 1996. Internest sex-ratio variation and male brood survival in the ant Pheidole pallidula. Behav. Ecol. 7:292-98

63. Kerr WE. 1969. Some aspects of the evolution of social bees (Apidae). Evol. Biol. 3:119-75

64. Koedam D, Monge IA, Sommeijer MJ. 1995. Social interactions of gynes and their longevity in queenright colonies of Melipona favosa (Apidae: Meliponinae). Neth. J. Zool. 45:480-94

64a. Korb J. 2005. Regulation of sexual development in the basal termite Cryptotermes secundus: mutilation, pheromonal manipulation or honest signal? Naturwissenschaften 92:45-49

64b. Korb J, Heinze J. 2004. Multilevel selection and social evolution of insect societies. Naturwissenschaften 91:291304

65. Krieger MJ, Ross KG. 2002. Identification of a major gene regulating complex social behavior. Science 295:328-32

66. Langer P, Hogendoorn K, Keller L. 2004. Tug-of-war over reproduction in a social bee. Nature 428:844-47

67. Liebig J, Peeters C, Hölldobler B. 1999. Worker policing limits the number of reproductives in a ponerine ant. Proc. R. Soc. London B Biol. Sci. 266:186570

68. Lopez-Vaamonde C, Koning JW, Brown RM, Jordan WC, Bourke AFG. 2004. Social parasitism by male-producing reproductive workers in a eusocial insect. Nature 430:557-60

69. Martin SJ, Beekman M, Wossler TC, Ratnieks FLW. 2002. Parasitic Cape honeybee workers, Apis mellifera capensis, evade policing. Nature 415:163-65

70. Martin SJ, Châline N, Ratnieks FLW, Jones GR. 2005. Searching for the eggmarking signal in honeybees. J. Negat. Res. 2:1-9

71. Maynard Smith J, Szathmáry E. 1995. The
Major Transitions in Evolution. Oxford, UK: Freeman

72. Mehdiabadi NJ, Reeve HK, Mueller UG. 2003. Queens versus workers: sex-ratio conflict in eusocial Hymenoptera. Trends Ecol. Evol. 18:88-93

73. Michener CD, Brothers DJ. 1974. Were workers of eusocial Hymenoptera initially altruistic or oppressed? Proc. Natl. Acad. Sci. USA 71:671-74

74. Monnin T, Peeters C. 1999. Dominance hierarchy and reproductive conflicts among subordinates in a monogynous queenless ant. Behav. Ecol. 10:32332

75. Monnin T, Ratnieks FLW. 1999. Reproduction versus work in queenless ants: when to join a hierarchy of hopeful reproductives? Behav. Ecol. Sociobiol.46:41322

76. Monnin T, Ratnieks FLW. 2001. Policing in queenless ponerine ants. Behav. Ecol. Sociobiol. 50:97-108

77. Monnin T, Ratnieks FLW, Jones GR, Beard R. 2002. Pretender punishment induced by chemical signalling in a queenless ant. Nature 419:61-65

77a. Moo-Valle H, Quezada-Euán JJG, Wenseleers T. 2001. The effect of food reserves on the production of sexual offspring in the stingless bee Melipona beecheii (Apidae, Meliponini). Insectes Soc. 48:398403

78. Myles TG. 1999. Review of secondary reproduction in termites (Insecta: Isoptera) with comments on its role in termite ecology and social evolution. Sociobiology 33:1-91

79. Nakata K. 1998. Absence of sexdifferential brood raising by workers in Diacamma sp. from Japan. Behav. Ecol. Sociobiol. 43:223-27

80. Nonacs P. 1986. Sex-ratio determination within colonies of ants. Evolution 40:199204

81. Nonacs P. 1993. Male parentage and sexual deception in the social Hymenoptera. In Evolution and Diversity of Sex 
Ratio in Insects And Mites, ed. DL Wrensch, MA Ebbert, pp. 384-401. New York: Chapman \& Hall

82. Nonacs P, Carlin NF. 1990. When can ants discriminate the sex of brood? A new aspect of queen-worker conflict. Proc. Natl. Acad. Sci. USA 87:9670-73

83. Nonacs P, Tobin JE. 1992. Selfish larvae: development and the evolution of parasitic behavior in the Hymenoptera. Evolution 46:1605-20

84. O’Donnell S. 1998. Reproductive caste determination in eusocial wasps (Hymenoptera: Vespidae). Annu. Rev. Entomol. 43:323-46

85. Oldroyd BP, Halling LA, Good G, Wattanachaiyingcharoen $\mathrm{W}$, Barron $\mathrm{AB}$, et al. 2001. Worker policing and worker reproduction in Apis cerana. Behav. Ecol. Sociobiol. 50:371-77

86. Oster GF, Wilson EO. 1978. Caste and Ecology in the Social Insects. Princeton, NJ: Princeton Univ. Press. 352 pp.

86a. Pamilo P. 1982. Genetic evolution of sexratios in eusocial Hymenoptera: allele frequency simulations. Am. Nat. 119:63856

87. Pamilo P. 1991. Evolution of colony characteristics in social insects. 1 . Sex allocation. Am. Nat. 137:83-107

88. Pamilo P. 1991. Evolution of colony characteristics in social insects. 2. Number of reproductive individuals. Am. Nat. 138:412-33

89. Passera L, Aron S, Bach D. 1995. Elimination of sexual brood in the argentine ant Linepithema humile: queen effect and brood recognition. Entomol. Exp. Appl. 75:203-12

90. Passera L, Aron S, Vargo EL, Keller L. 2001. Queen control of sex ratio in fire ants. Science 293:1308-10

91. Peeters C, Billen J, Hölldobler B. 1992. Alternative dominance mechanisms regulating monogyny in the queenless ant genus Diacamma. Naturwissenschaften 79:572-73

92. Platt TG, Queller DC, Strassmann JE.
2004. Aggression and worker control of caste fate in a multiple-queen wasp, Parachartergus colobopterus. Anim. Behav. 67:1-10

93. Queller DC, Strassmann JE. 1998. Kin selection and social insects. Bioscience 48:165-75

94. Queller DC, Strassmann JE, Solis CR, Hughes CR, DeLoach DM. 1993. A selfish strategy of social insect workers that promotes social cohesion. Nature 365:639-41

95. Ratnieks FLW. 1988. Reproductive harmony via mutual policing by workers in eusocial Hymenoptera. Am. Nat. 132:217-36

96. Ratnieks FLW. 1991. Facultative sex allocation biasing by workers in social Hymenoptera. Evolution 45:218-92

97. Ratnieks FLW. 1991. The evolution of genetic odor-cue diversity in social Hymenoptera. Am. Nat. 137:202-26

98. Ratnieks FLW. 1993. Egg-laying, eggremoval, and ovary development by workers in queenright honey-bee colonies. $\mathrm{Be}$ hav. Ecol. Sociobiol. 32:191-98

99. Ratnieks FLW. 2001. Heirs and spares: caste conflict and excess queen production in Melipona bees. Behav. Ecol. Sociobiol. 50:467-73

100. Ratnieks FLW, Reeve HK. 1992. Conflict in single-queen hymenopteran societies: the structure of conflict and processes that reduce conflict in advanced eusocial species. J. Theor. Biol. 158:3365

101. Ratnieks FLW, Visscher PK. 1989. Worker policing in the honeybee. Nature 342:796-97

102. Ratnieks FLW, Wenseleers T. 2005. Policing insect societies. Science 307:5456

103. Reeve HK, Keller L. 2001. Tests of reproductive-skew models in social insects. Annu. Rev. Entomol. 46:347-85

104. Reeve HK, Peters JM, Nonacs P, Starks PT. 1998. Dispersal of first "workers" in social wasps: causes and implications 
of an alternative reproductive strategy. Proc. Natl. Acad. Sci. USA 95:1373742

105. Reuter M, Helms KR, Lehmann L, Keller L. 2004. Effects of brood manipulation costs on optimal sex allocation in social Hymenoptera. Am. Nat. 164:E73-82

106. Reuter M, Keller L. 2001. Sex ratio conflict and worker production in eusocial Hymenoptera. Am. Nat. 158:166-77

107. Robinson GE, Ben-Shahar Y. 2002. Social behavior and comparative genomics: new genes or new gene regulation? Genes Brain Behav. 1:197-203

108. Rüppell O, Heinze J, Hölldobler B. 2002. Intracolonial patterns of reproduction in the queen-size dimorphic ant Leptothorax rugatulus. Behav. Ecol. 13:239-47

109. Sachs JL, Mueller UG, Wilcox TP, Bull JJ. 2004. The evolution of cooperation. $Q$. Rev. Biol. 79:135-60

110. Saigo T, Tsuchida K. 2004. Queen and worker policing in monogynous and monandrous colonies of a primitively eusocial wasp. Proc. R. Soc. London B Biol. Sci. 271:S509-S12

111. Sanada S, Satoh T, Obara Y. 1999. How average relatedness affects the frequency of trophallaxis between workers in an experimental colony of the polygynous ant, Camponotus yamaokai. J. Ethol. 16:4348

112. Schneirla TC. 1971. Army Ants: A Study in Social Organisation. San Francisco: Freeman. 349 pp.

113. Seeley TD. 1995. The Wisdom of the Hive: The Social Physiology of Honey Bee Colonies. Cambridge, MA: Harvard Univ. Press. 309 pp.

114. Snyder LE. 1993. Non-random behavioural interactions among genetic subgroups in a polygynous ant. Anim. Behav. 46:431-39

115. Strassmann J. 2001. The rarity of multiple mating by females in the social Hymenoptera. Insectes Soc. 48:1-13

116. Strassmann JE. 1989. Early termination of brood rearing in the social wasp, Polistes annularis (Hymenoptera, Vespidae). $J$. Kans. Entomol. Soc. 62:353-62

117. Strassmann JE. 2001. The rarity of multiple mating by females in the social hymenoptera. Insectes Soc. 48:1-13

118. Strassmann JE, Klingler CJ, Arevalo E, Zacchi F, Husain A, et al. 1997. Absence of within-colony kin discrimination in behavioural interactions of swarmfounding-wasps. Proc. R. Soc. London B Biol. Sci. 264:1565-70

119. Strassmann JE, Seppä P, Queller DC. 2000. Absence of within-colony kin discrimination: Foundresses of the social wasp, Polistes carolina, do not prefer their own larvae. Naturwissenschaften 87:26669

120. Strassmann JE, Sullender BW, Queller DC. 2002. Caste totipotency and conflict in a large-colony social insect. Proc. $R$. Soc. London B Biol. Sci. 269:263-70

121. Sundström L. 1994. Sex ratio bias, relatedness asymmetry and queen mating frequency in ants. Nature 367:266-67

122. Sundström L, Chapuisat M, Keller L. 1996. Conditional manipulation of sex ratios by ant workers: a test of kin selection theory. Science 274:993-95

123. Sundström L, Ratnieks FLW. 1998. Sex ratio conflicts, mating frequency, and queen fitness in the ant Formica truncorum. Behav. Ecol. 9:116-21

124. Tarpy DR, Gilley DC, Seeley TD. 2004. Levels of selection in a social insect: a review of conflict and cooperation during honey bee (Apis mellifera) queen replacement. Behav. Ecol. Sociobiol. 55:513-23

125. Trivers RL, Hare H. 1976. Haplodiploidy and the evolution of the social insects. Science 191:249-63

126. van Veen JW, Sommeijer MJ. 2000. Colony reproduction in Tetragonisca angustula (Apidae, Meliponini). Insectes Soc. 47:70-75

127. Visscher PK. 1986. Kinship discrimination in queen rearing by honey bees (Apis mellifera). Behav. Ecol. Sociobiol. 18:453-60 
128. Visscher PK. 1989. A quantitative study of worker reproduction in honeybee colonies. Behav. Ecol. Sociobiol. 25:24754

129. Visscher PK. 1996. Reproductive conflict in honey bees: a stalemate of worker egglaying and policing. Behav. Ecol. Sociobiol. 39:237-44

130. Visscher PK. 1998. Colony integration and reproductive conflict in honey bees. Apidologie 29:23-45

131. Watson JAL, Okot-Kotber BM, Noirot C, eds. 1985. Caste Differentiation in Social Insects. Oxford, UK: Pergamon. 405 pp.

132. Wenseleers T, Badcock NS, Erven K, Tofilski A, Nascimento FS, et al. 2005. A test of worker policing theory in an advanced eusocial wasp, Vespula rufa. Evolution 59:1306-14

133. Wenseleers T, Billen J. 2000. No evidence for Wolbachia-induced parthenogenesis in the social Hymenoptera. J. Evol. Biol. 13:277-80

134. Wenseleers T, Hart AG, Ratnieks FLW. 2004. When resistance is useless: policing and the evolution of reproductive acquiescence in insect societies. Am. Nat. 164: E154-67

135. Wenseleers T, Hart AG, Ratnieks FLW, Quezada-Euán JJG. 2004. Queen execution and caste conflict in the stingless bee Melipona beecheii. Ethology 110:725-36

136. Wenseleers T, Helanterä H, Hart AG, Ratnieks FLW. 2004. Worker reproduction and policing in insect societies: an ESS analysis. J. Evol. Biol. 17:1035-47

137. Wenseleers T, Ito F, Van Borm S, Huybrechts R, Volckaert F, et al. 1998. Widespread occurrence of the micro- organism Wolbachia in ants. Proc. R. Soc. London Ser. B Biol. Sci. 265:1447-52

138. Wenseleers T, Ratnieks FLW. 2004. Tragedy of the commons in Melipona bees. Proc. R. Soc. London Ser. B Biol. Sci. 271:S310-12

139. Wenseleers T, Ratnieks FLW. 2005. Comparative analysis supports relatedness theory for worker policing in eusocial Hymenoptera. Am. Nat. In press

140. Wenseleers T, Ratnieks FLW, Billen J. 2003. Caste fate conflict in swarmfounding social Hymenoptera: an inclusive fitness analysis. J. Evol. Biol. 16:64758

141. Wenseleers T, Ratnieks FLW, Ribeiro MF, Alves DA, Imperatriz-Fonseca V-L. 2005. Working-class royalty: Bees beat the caste system. Biol. Lett. 1:125-8

142. Wenseleers T, Sundström L, Billen J. 2002. Deleterious Wolbachia in the ant Formica truncorum. Proc. R. Soc. London Ser. B Biol. Sci. 269:623-9

143. Wenseleers T, Tofilski A, Ratnieks FLW. 2005. Queen and worker policing in the tree wasp Dolichovespula sylvestris. Behav. Ecol. Sociobiol. 58:80-86

144. Wilson EO. 1971. The Insect Societies. Cambridge, MA: Harvard Univ. Press

145. Winston ML. 1987. The Biology of the Honey Bee. Cambridge, MA: Harvard Univ. Press

146. Yanega D. 1988. Social plasticity and early-diapausing females in a primitively social bee. Proc. Natl. Acad. Sci. USA 85:4374-77

147. Zimmerman RB. 1983. Sibling manipulation and indirect fitness in termites. Behav. Ecol. Sociobiol. 12:143-45 


\section{Box S1 The effect of relatedness on conflict resolution in insect societies}

Inclusive fitness theory (40) can be used to determine the optimum reproductive strategies for individuals in male production and female caste conflict $(108,109$, 112). That is, whether to attempt to reproduce directly or to work. The analysis determines the ESS (evolutionarily stable) (71) proportion which should work when coercion against attempted reproduction does not occur so that cost to kin is the only factor limiting direct reproduction and hence resolving the conflict. Concerning male production by workers, the ESS ratio of reproductive to sterile workers in a queenright colony is

\section{$\left[R_{s}-R_{m}\right]$ reproductive workers to $\left[R_{f}+R_{m}\right]$ sterile workers}

where $R_{s}, R_{f}$ and $R_{m}$ are the (life-for-life) relatedness coefficients (10) of workers to sons, sisters and males reared in the colony (109). The inclusive fitness benefit to a worker from reproducing is to replace an average male (value $R_{m}$ ) by a son (value $R_{s}$ ), which gives $\left(R_{s}-R_{m}\right)$. The benefit of becoming a sterile worker is to increase colony productivity, which entails both queen (value $R_{f}$ ) and male production (value $R_{m}$ ), which gives $\left(R_{f}+R_{m}\right)$. The ratio gives an ESS proportion of workers that should reproduce of $\left(R_{s}-R_{m}\right) /\left(R_{f}+R_{s}\right)$. At the ESS reproductive and non-reproductive workers have equal inclusive fitness (109). In large colonies, the algebra becomes very simple because unpoliced worker reproduction will result in workers' sons dominating male production so that workers rear mainly nephews. In addition, if the majority of males in the population are workers' sons, male reproductive value is increased (10) so that the relatedness of workers to nephews and sisters is equal $\left(R_{m}=R_{f}\right)$ and relatedness to sons is $1\left(R_{s}=1\right)$. This gives ESS proportions of egglaying workers of $14 \%, 33 \%$, and $54 \%$ (109) for relatednesses among workers of $0.75,0.5$, and 0.3 , corresponding to paternity frequencies of 1,2 and 10 . These results confirm the basic prediction that low relatedness causes greater potential conflict. A similar analysis of caste fate conflict for swarm-founding species $(108,112)$ showed that individual females should develop into queens versus workers in a ratio of

\section{$\left[1-R_{f}\right]$ queens to $\left[R_{f}+R_{m}\right]$ workers}

Again, this represents the relative inclusive fitness of the alternative strategies. The strategy of becoming a queen has a direct benefit $\left(1-R_{f}\right)$ but becoming a worker has an indirect benefit in terms of increased colony productivity $\left(R_{f}+R_{m}\right)$, giving an ESS proportion of workers developing into queens of $\left(1-R_{f}\right) /\left(1+R_{m}\right)(112)$. Thus, in stingless bees, where the mother queen is singly mated $\left(R_{f}=0.75\right)$, between $14 \%$ and $20 \%$ of the larvae should develop as queens, depending on whether the males are workers' sons $\left(R_{m}=0.75\right)$ or the queen's sons $\left(R_{m}=0.25\right)(90,112)$. In the honeybee, however, queens mate with approximately 10 males, so that $R_{f}=0.3$ and almost all males are the queen's sons so that $R_{m} \cong 0.25$. Thus, the ESS in honeybees in the absence of coercion is for $56 \%$ of all female larvae to develop into queens (112). The 
above results are based on the assumption that colony-level costs scale linearly with the proportion of individuals that act selfishly by attempting to reproduce directly. This assumption can easily be relaxed $(109,112)$. However, the general result is unaltered. Greater kinship results in fewer individuals following the selfish strategy of direct reproduction versus working, and in all cases a large proportion of individuals should adopt the selfish strategy $(109,112)$.

\section{Box S2 Information and conflict resolution}

Information often affects the outcome of reproductive conflicts because exercising power in a conflict situation frequently involves discrimination among kin (5). For example, workers must recognize the sex of larvae to manipulate sex allocation, recognize whether an egg is laid by the queen or a worker to police worker-laid eggs, and recognize full-sister and half-sister queens in order to favor the fullsisters. Recognition need not be perfect but the better the information the fewer the errors and the greater the advantage. If errors are sufficiently high then the costs of discrimination can outweigh the benefits $(59,91)$. Individuals subject to discrimination may be selected to conceal, advertize or mimic information. Thus, a queen honey bee is selected to advertize that her eggs are queen-laid (86) because workers should favor queen-laid eggs if they can recognize them as workers are more related to brothers $(0.25)$ than nephews $(0.15)$. But egg-laying workers will benefit if they can lay eggs that mimic queen-laid eggs as this will increase egg survival (69, 86). Male larvae may be selected to mimic female larvae and to conceal their maleness in order to increase their chances of being reared $(78,79)$. Depending on the context, conflict resolution may result from either good information (low errors) or poor information. If police workers have good information they can easily discriminate between worker-laid eggs and queen-laid eggs. This will make policing more effective, select for fewer workers to lay eggs and help to resolve the conflict over male production $(108,109,111)$. If workers have poor information to recognize full-sister and half-sister queens then discrimination in queen rearing is not favored (87) and the conflict over queen rearing is resolved. If the workers have good information concerning the sex of young brood this will make manipulating the sex ratio easier and could lead to the conflict being resolved close to the worker optimum, provided that there are sufficient female larvae available to rear additional queens (82). Conversely, poor information would make manipulation of the sex ratio costly and lead to a resolution close to the queen optimum. The information useful in different contexts almost certainly varies greatly in quality. Thus, discrimination between full-sister and half-sister queens must use phenotypic odors based on underlying heritable variation (87), and requires discriminatory workers to use their own odor as a referent with which to compare queens. The information available is almost certainly insufficient to recognize full- versus half-sisters accurately $(7,87)$. Discrimination between worker-laid eggs and queen-laid eggs could be very accurate if queens marked their eggs with a special pheromone $(69,86)$, provided that workers did not mimic this (4). 


\section{Table S1 Queen and worker policing in the social Hymenoptera}

Policing can be carried out by the queen or workers, and can occur via either aggression (A) or egg-eating (E) or both. When police workers were observed to reproduce, policing is indicated as being selfish (113), i.e. driven by direct reproductive motives. In bumblebees, there are anecdotal observations of workers eating other workers' eggs and queen's eggs (12, 13, 27, 31-33, 50, 52, 56, 57, 67, 98, 99, 103 , 105). However, egg eating is probably not discriminatory, and so this is not considered worker policing.

\begin{tabular}{|c|c|c|c|c|}
\hline $\begin{array}{l}\text { TAXON } \\
\text { Species }\end{array}$ & $\begin{array}{l}\text { Queen } \\
\text { policing } \\
\text { (A/E) }\end{array}$ & $\begin{array}{l}\text { Worker } \\
\text { policing } \\
\text { (A/E) }\end{array}$ & $\begin{array}{l}\text { Worker } \\
\text { policing } \\
\text { selfish? }\end{array}$ & References \\
\hline \multicolumn{5}{|l|}{ ANTS } \\
\hline Acromyrmex echinatior & no & yes (E) & $\mathrm{no}^{\mathrm{a}}$ & (20) \\
\hline Aphaenogaster cockerelli & no & yes (A) & no data & (51) \\
\hline Aphaenogaster senilis & no & yes (A) & yes $^{\mathrm{b}}$ & (64) \\
\hline Aphaenogaster smythiesi & no & yes (A) & no data & (54) \\
\hline Camptonotus floridanus & no data & yes $(E)$ & no data & $(21)$ \\
\hline Crematogaster smithii & $\operatorname{yes}^{c}(E)$ & no & & $(44,47)$ \\
\hline Diacamma sp. & yes $(E)$ & yes $(A+E)$ & no data & $(60,77)$ \\
\hline Dinoponera quadriceps & yes $(A+E)$ & no & & $(75,76)$ \\
\hline Eutetramorium mocquerysi & yes $(A+E)$ & no & & $(45)$ \\
\hline Formica fusca & no & yes $(\mathrm{E})$ & no data & $(48,49)$ \\
\hline Gnamptogenys menadensis & no & yes (A) & no & $(34,35)$ \\
\hline Harpegnathos saltator & no & yes (A) & no & (66) \\
\hline Leptothorax acervorum & yes $(E)$ & no & & $(9,41)$ \\
\hline Lordomyrma sp. & yes (A) & no & & $(16)$ \\
\hline Odontomachus rixosus & yes (E) & no data & & (53) \\
\hline Odontomachus simillimus & yes (E) & no data & & (104) \\
\hline Pachycondyla inversa & no & yes $(E)$ & no data & (18) \\
\hline Platythyrea punctata & no & $\operatorname{yes}^{\mathrm{d}}(\mathrm{A})$ & no data & (43) \\
\hline Protomognathus americanus & yes $(\mathrm{A})$ & yes (A) & yes $^{b}$ & $(8,22,30,46)$ \\
\hline \multicolumn{5}{|l|}{ WASPS (VESPINAE) } \\
\hline Dolichovespula arenaria & yes $(A+E)$ & no data & & $(37,38)$ \\
\hline Dolichovespula maculata & yes $(A+E)$ & yes $(A+E)$ & yes? ${ }^{\mathrm{e}}$ & (37) \\
\hline Dolichovespula media & yes (E) & no data & & (26) \\
\hline Dolichovespula norwegica & yes $(A+E)$ & (yes, but rare) & no data & (1) \\
\hline Dolichovespula saxonica & yes (E) & $\operatorname{yes}^{f}(A+E)$ & no data & $(24,26)$ \\
\hline Dolichovespula sylvestris & yes $(A+E)$ & yes $(A+E)$ & yes $^{\mathrm{g}}$ & $(113,114)$ \\
\hline Vespa crabro & no & yes (E) & no data & (23) \\
\hline Vespula acadica & yes (A) & no data & & (93) \\
\hline Vespula atropilosa & no & yes (A+E?) & no & $(38,63)$ \\
\hline Vespula rufa & yes $(A+E)$ & (yes, but rare) & yes $^{\text {h }}$ & (107) \\
\hline Vespula vulgaris & no & yes $(\mathrm{E})$ & no & $(25,115)$ \\
\hline \multicolumn{5}{|l|}{ WASPS (POLISTINAE) } \\
\hline Polistes biglumis & no data & yes (E) & yes? ${ }^{\mathrm{e}}$ & $(74)$ \\
\hline Polistes chinensis & yes $(A+E)$ & yes (E) & yes $^{\mathrm{g}}$ & $(94,101,102)$ \\
\hline Polistes dominulus & yes (E) & yes $(\mathrm{E})$ & yes $^{\mathrm{g}}$ & $(65,85)$ \\
\hline Parachartergus smithii & yes (E) & no data & & (2) \\
\hline
\end{tabular}




\title{
HONEYBEES
}

Apis cerana

Apis florea

Apis mellifera capensis

Apis mellifera mellifera,

A. m. ligustica or hybrid

Apis mellifera scutellata

$\begin{array}{llll}\text { no } & \text { yes }(E) & \text { no }^{\mathrm{a}} & (80) \\ \text { no } & \text { yes }(E)^{\mathrm{d}} & \text { no }^{\mathrm{a}} & (39) \\ \text { no } & \text { yes }^{\mathrm{a}}(\mathrm{E}) & \text { no data } & (83) \\ \text { no } & \text { yes }(\mathrm{A}+\mathrm{E}) & \text { no }^{\mathrm{a}} & (58,70,73,81,88,89, \\ & & & 92,95,106) \\ \text { no } & \text { yes }(\mathrm{E}) & \text { no }^{\mathrm{a}} & (28,68,83)\end{array}$

\section{STINGLESS BEES \\ Melipona bicolor \\ Melipona compressipes \\ Melipona scutellaris \\ Scaptotrigona depilis \\ Scaptotrigona postica}

$\begin{array}{ll}\text { yes }(E) & \text { yes }(E) \quad \text { yes }^{\text {g }} \\ \text { yes (E) } & \text { no } \\ \text { yes (E) } & \text { no } \\ \text { yes (E) } & \text { no } \\ \text { yes (E) } & \text { no }\end{array}$

$(61,62,105)$

(6)

\section{BUMBLEBEES}

Bombus agrorum

Bombus ardens

Bombus atratus

Bombus ephippiatus

Bombus hypocrita

Bombus ignitus

Bombus impatiens

Bombus lapidarius

Bombus ruderatus

Bombus terrestris

$\begin{array}{ll}\text { yes }(A) & \text { no } \\ \text { yes }(A+E) & \text { no } \\ \text { yes }(A+E) & \text { no } \\ \text { yes }(E) & \text { no } \\ \text { yes }(A+E) & \text { no } \\ \text { yes }(A) & \text { no } \\ \text { yes }(E) & \text { no } \\ \text { yes }(A+E) & \text { no } \\ \text { yes }(A+E) & \text { no } \\ \text { yes }(A+E) & \text { no }\end{array}$

\section{SWEAT BEES}

Lasioglossum zephyrum

yes $(\mathrm{A}+\mathrm{E})$

$(11,14,15,36,72)$

\begin{abstract}
ajudged from the extreme rarity of workers with active ovaries in queenright colonies. ${ }^{\mathrm{b}}$ Only reproductive workers ag-

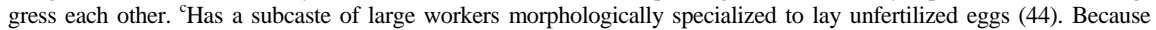
many of these worker-laid eggs were eaten by the queen, these eggs were initially thought to have a purely trophic function (44). However, a later genetic study (47) showed that a significant proportion of the adult males were workers' sons, implying that many of the eggs were in fact viable. Hence, egg eating by the queen is probably best interpreted as queen policing. ${ }^{\mathrm{d}}$ Workers police female eggs laid by other workers, produced by thelytokous parthenogenesis. ${ }^{\mathrm{e}}$ Authors refer to competitive oviposition and oophagy among workers, implying that worker policing was probably selfish. ${ }^{\text {fPrimarily in }}$ multiple paternity colonies. ${ }^{g}$ Workers replace other workers' eggs. ${ }^{\mathrm{h}} \mathrm{In}$ two out of the eight cases where a worker policed a worker-laid egg (107), the policing worker laid an egg soon after (1).
\end{abstract}

\section{LITERATURE CITED IN SUPPLEMENTAL MATERIAL}

1. T Wenseleers, A Tofilski, FS Nascimento and FLW Ratnieks, unpubl. data

2. FS Nascimento, pers. comm.

3. JI Cuadriello-Aguilar, pers. comm.

4. Barron AB, Oldroyd BP, Ratnieks FLW. 2001. Worker reproduction in honeybees (Apis) and the anarchic syndrome: a review. Behav. Ecol. Sociobiol. 50:199208

5. Beekman M, Ratnieks FLW. 2003.
Power over reproduction in social Hymenoptera. Philos. Trans. R. Soc. London Ser. B Biol. Sci. 358:1741-53

6. Bego LR. 1990. On social regulation in Nannotrigona (Scaptotrigona) postica Latreille with special reference to productivity of colonies (Hymenoptera, Apidae, Meliponinae). Rev. Bras. Entomol. 34:721-38

7. Boomsma JJ, Nielsen J, Sundström L, Oldham NJ, Tentschert J, et al. 2003. Informational constraints on optimal sex 
allocation in ants. Proc. Natl. Acad. Sci. USA 100:8799-804

8. Bourke AFG. 1988. Dominance orders, worker reproduction, and queen-worker conflict in the slave-making ant Harpa- 19 goxenus sublaevis. Behav. Ecol. Sociobiol. 23:323-33

9. Bourke AFG. 1991. Queen behavior, reproduction and egg cannibalism in multiple-queen colonies of the ant Leptothorax acervorum. Anim. Behav. 42:295- 20. 310

10. Bourke AFG, Franks NR. 1995. Social Evolution in Ants. Princeton, New Jersey: Princeton University Press. 529 pp.

11. Breed MD, Gamboa GJ. 1977. Behavioral control of workers by queens in primitively eusocial bees. Science 195:694-6

12. Brian AD. 1951. Brood development in Bombus agrorum (Hym., Bombidae). Entomol. Monthl. Mag. 87:207-12

13. Brian AD. 1952. Division of labour and foraging in Bombus agrorum Fabricius. J. Anim. Ecol. 21:223-40

14. Buckle GR. 1982. Queen-worker behavior and nesmate interactions in young colonies of Lasioglossum zephyrum. Insectes Soc. 29:125-37

15. Buckle GR. 1984. A second look at queen-forager interactions in the primitively eusocial halictid, Lasioglossum zephyrum. J. Kans. Entomol. Soc. 57:1-6

16. Casteels J, Ito F, Billen J, Gobin B. 2003. Queen policing of worker reproduction in the ant Lordomyrma sp. Presented at the Colloque Annuel de la Section Française de l'UIEIS, Bruxelles

17. Cnaani J, Schmid-Hempel R, Schmidt JO. 2002. Colony development, larval development and worker reproduction in Bombus impatiens Cresson. Insectes Soc. 49:164-70

18. D'Ettorre P, Heinze J, Ratnieks FLW.
2004. Worker policing by egg-eating in the ponerine ant Pachycondyla inversa. Proc. R. Soc. London Ser. B Biol. Sci. 271:1427-34

da Silva PR, Bego LR, Sakagami SF. 2001. On the cell provisioning and oviposition process (POP) of the stingless bee Scaptotrigona aff. depilis (Hymenoptera: Meliponinae). Sociobiology 38:615-38

Dijkstra M, Boomsma JJ. 2004. Reproductive self-restraint without effective policing in workers of Acromyrmex echinatior leafcutter ants. Presented at the Closing Symposium of the EU Research Training Network INSECTS, Lo-Skolen, Helsingoer, Denmark

21. Endler A, Liebig J, Schmitt T, Parker JE, Jones GR, et al. 2004. Surface hydrocarbons of queen eggs regulate worker reproduction in a social insect. Proc. Natl. Acad. Sci. USA 101:2945-50

22. Foitzik S, Herbers JM. 2001. Colony structure of a slavemaking ant. I. Intracolony relatedness, worker reproduction, and polydomy. Evolution 55:307-15

23. Foster KR, Gulliver J, Ratnieks FLW. 2002. Worker policing in the European hornet Vespa crabro. Insectes Soc. 49:41-4

24. Foster KR, Ratnieks FLW. 2000. Facultative worker policing in a wasp. Nature 407:692-3

25. Foster KR, Ratnieks FLW. 2001. Convergent evolution of worker policing by egg eating in the honeybee and common wasp. Proc. R. Soc. London Ser. B Biol. Sci. 268:169-74

26. Foster KR, Ratnieks FLW. 2001. Paternity, reproduction and conflict in vespine wasps: a model system for testing kin selection predictions. Behav. Ecol. Sociobiol. 50:1-8

27. Foster RL, Brunskill A, Verdirame D, O'Donnell S. 2004. Reproductive physiology, dominance interactions, and divi- 
sion of labour among bumble bee workers. Physiol. Entomol. 29:327-34

28. Franck P, Koeniger N, Lahner G, Crewe 39. RM, Solignac M. 2000. Evolution of extreme polyandry: an estimate of mating frequency in two African honeybee subspecies, Apis mellifera monticola and A.m. scutellata. Insectes Soc. 47:364-70

29. Frank SA. 1998. The Foundations of Social Evolution. Princeton, New Jersey: Princeton University Press. 259 pp.

30. Franks NR. 1983. Dominance and reproductive success among slavemaking worker ants. Nature 304:24-5

31. Free JB. 1955. The behaviour of egg- 42 . laying workers of bumblebee colonies. Br. J. Anim. Beh. 3:147-53

32. Free JB. 1955. Queen production in 43. colonies of bumblebees. Proc. R. Entomol. Soc. London Ser. A Gen. Entomol. 30:19-25

33. Free JB, Weinberg I, Whiten A. 1969. 44. The egg-eating behaviour of Bombus lapidarius L. Behaviour 35:313-7

34. Gobin B, Billen J, Peeters C. 1999. Policing behaviour towards virgin egg layers in a polygynous ponerine ant. 45 . Anim. Behav. 58:1117-22

35. Gobin B, Billen J, Peeters C. 2001. Dominance interactions regulate worker mating in the polygynous ponerine ant Gnamptogenys menadensis. Ethology 107:495-508

36. Greenberg L, Buckle GR. 1981. Inhibition of worker mating by queens in a sweat bee, Lasioglossum zephyrum. Insectes Soc. 28:347-52

37. Greene A. 1979. Behavioural characters as indicators of yellowjacket phylogeny (Hymenoptera: Vespidae). Ann. Entomol. Soc. Am. 72:614-9

38. Greene A, Akre RD, Landolt P. 1976. The aerial yellowjacket Dolichovespula arenaria (Fab.): nesting biology, reproductive production, and behaviour (Hy- menoptera: Vespidae). Melanderia 26:134

Halling LA, Oldroyd BP, Wattanachaiyingcharoen $\mathrm{W}$, Barron $\mathrm{AB}$, Nanork P, et al. 2001. Worker policing in the bee Apis florea. Behav. Ecol. Sociobiol. 49:509-13

40. Hamilton WD. 1964. The genetical evolution of social behaviour. I and II. $J$. Theor. Biol. 7:1-52

41. Hammond RL, Bruford MW, Bourke AFG. 2003. Male parentage does not vary with colony kin structure in a multiple-queen ant. J. Evol. Biol. 16:446-55

Hammond RL, Keller L. 2004. Conflict over male parentage in social insects. PLoS Biol. 2:1-11

Hartmann A, Wantia J, Torres JA, Heinze J. 2003. Worker policing without genetic conflicts in a clonal ant. Proc. Natl. Acad. Sci. USA 100:12836-40

Heinze J, Foitzik S, Oberstadt B, Rüppell O, Hölldobler B. 1999. A female caste specialized for the production of unfertilized eggs in the ant Crematogaster smithi. Naturwissenschaften 86:93-5

Heinze J, Hölldobler B, Alpert G. 1999. Reproductive conflict and division of labor in Eutetramorium mocquerysi, a myrmicine ant without morphologically distinct female reproductives. Ethology 105:701-17

46. Heinze J, Ortius D, Kaib M, Hölldobler B. 1994. Interspecific aggression in colonies of the slave-making ant Harpagoxenus sublaevis. Behav. Ecol. Sociobiol. 35:75-83

47. Heinze J, Stratz M, Pedersen JS, Haberl M. 2000. Microsatellite analysis suggests occasional worker reproduction in the monogynous ant Crematogaster smithi. Insectes Soc. 47:299-301

48. Helanterä H. 2004. Kinship and conflicts over male production in Formica ants. $\mathrm{PhD}$ thesis. University of Helsinki. 112 pp. 
49. Helanterä H., Sundström L. 2005. Worker reproduction in the ant Formica fusca. J. Evol. Biol. 18:162-171

50. Hoffer E. 1882-83. Die Hummeln 59. Steiermarks. Lebensgeschichte und Beschreibung derselben. Graz: Leuschner and Lubensky

51. Hölldobler B, Carlin NF. 1989. Colony founding, queen control and worker reproduction in the ant Aphaenogaster (=Novomessor) cockerelli (Hymenoptera: Formicidae). Psyche 96:131-51

52. Huber P. 1802. Observations on several species of the genus Apis, known by the name of humble-bees, and called Bombinatrices by Linnaeus. Trans. Linn. Soc. Lond. 6:214-98

53. Ito F, Yusoff NR, Idris AH. 1996. Colony composition and queen behavior in polygynous colonies of the Oriental ponerine ant Odontomachus rixosus (Hymenoptera Formicidae). Insectes Soc. 43:77-86

54. Iwanishi S, Hasegawa E, Ohkawara K. 2003. Worker oviposition and policing behaviour in the myrmicine ant Aphaenogaster smythiesi japonica Forel. Anim. Behav. 66:513-9

55. Katayama E. 1971. Observation on the brood development in Bombus ignitus (Hymenoptera, Apidae). I. Egg-laying habits of queens and workers. Kontyu 39:189-203

56. Katayama E. 1974. Egg-laying habits and brood development in Bombus hypocrita (Hymenoptera, Apidae). 1. Egglaying habits of queens and workers. Kontyu 42:416-38

57. Katayama E. 1997. Oviposition and oophagy by workers in queenright colonies of Bombus (Pyrobombus) ardens (Hymenoptera, Apidae). Jpn. J. Entomol. 65:23-35

58. Katzav-Gozansky T, Soroker V, Ibarra F, Francke W, Hefetz A. 2001. Dufour's gland secretion of the queen honeybee
(Apis mellifera): an egg discriminator pheromone or a queen signal? Behav. Ecol. Sociobiol. 51:76-86

Keller L. 1997. Indiscriminate altruism: unduly nice parents and siblings. Trends Ecol. Evol. 12:99-103

60. Kikuta N, Tsuji K. 1999. Queen and worker policing in the monogynous and monandrous ant, Diacamma sp. Behav. Ecol. Sociobiol. 46:180-9

61. Koedam D, Cepada OI, ImperatrizFonseca V-L. 2005. Reproduction and oophagy by workers in the polygynous stingless bee Melipona bicolor (Hymenoptera: Meliponini). Apidologie In press

62. Koedam D, Velthuis HHW, Dohmen MR, Imperatriz-Fonseca VL. 2001. The behaviour of laying workers and the morphology and viability of their eggs in Melipona bicolor bicolor. Physiol. Entomol. 26:254-9

63. Landolt PJ, Akre RD, Greene A. 1977. Effects of colony division on Vespula atropilosa (Sladen) (Hymenoptera: Vespidae). J. Kans. Entomol. Soc. 50:135-47

64. Lenoir A, Ichinose K. 2004. Worker policing in a highly evolved ant. Presented at the Closing Symposium of the EU Research Training Network INSECTS, Lo-Skolen, Helsingoer, Denmark

65. Liebig J, Monnin T, Turillazzi S. 2005. Direct assessment of queen quality and lack of worker suppression in a paper wasp. Proc. R. Soc. London Ser. B Biol. Sci. 272:1339-1344

66. Liebig J, Peeters C, Hölldobler B. 1999. Worker policing limits the number of reproductives in a ponerine ant. Proc. $R$. Soc. London Ser. B Biol. Sci. 266:186570

67. Lindhard E. 1912. Humelbien som Husdyr. Spredte Træk of nogle danske Humlebiarters Biologi. Tidsskr. Landbrugets Planteavl. 19:335-52

68. Martin SJ, Beekman M, Wossler TC, 
Ratnieks FLW. 2002. Parasitic Cape honeybee workers, Apis mellifera capensis, evade policing. Nature 415:163-5

69. Martin SJ, Châline N, Ratnieks FLW, Jones GR. 2005. Searching for the eggmarking signal in honeybees. J. Negat. 79. Res. 2:1-9

70. Martin SJ, Jones GR, Châline N, Middleton H, Ratnieks FLW. 2002. Reassessing the role of the honeybee (Apis mellifera) 80. Dufour's gland in egg marking. Naturwissenchaften 89:528-32

71. Maynard Smith J. 1982. Evolution and the Theory of Games. New York: Cambridge University Press. 224 pp.

72. Michener CD, Brothers DJ. 1974. Were workers of eusocial Hymenoptera initially altruistic or oppressed? Proc. Natl. Acad. Sci. USA 71:671-4

73. Miller DG, Ratnieks FLW. 2001. The timing of worker reproduction and breakdown of policing behaviour in queenless honey bee (Apis mellifera L.) societies. Insectes Soc. 48:178-84

74. Miyano S. 1983. Number of offspring and seasonal changes of their body weight in a paper wasp, Polistes chinensis antennalis Pérez (Hymenoptera, Vespidae), with reference to male pro- 84 duction by workers. Res. Pop. Ecol. 25:198-209

75. Monnin T, Peeters C. 1997. Cannibalism of subordinates' eggs in the monogynous 85 . queenless ant Dinoponera quadriceps. Naturwissenschafren 84:499-502

76. Monnin T, Ratnieks FLW, Jones GR, Beard R. 2002. Pretender punishment in- 86 duced by chemical signalling in a queenless ant. Nature 419:61-5

77. Nakata K, Tsuji K. 1996. The effect of colony size on conflict over male- 87. production between gamergate and dominant workers in the ponerine ant Diacamma sp. Ethol. Ecol. Evol. 8:14756

78. Nonacs P. 1993. Male parentage and sexual deception in the social Hymenoptera. In Evolution and diversity of sex ratio in insects and mites, ed. DL Wrensch, MA Ebbert, pp. 384-401. New York: Chapman and Hall

79. Nonacs P, Carlin NF. 1990. When can ants discriminate the sex of brood? A new aspect of queen-worker conflict. Proc. Natl. Acad. Sci. USA 87:9670-3

Oldroyd BP, Halling LA, Good G, Wattanachaiyingcharoen $\mathrm{W}$, Barron $\mathrm{AB}$, et al. 2001. Worker policing and worker reproduction in Apis cerana. Behav. Ecol. Sociobiol. 50:371-7

81. Oldroyd BP, Ratnieks FLW. 2000. Evolution of worker sterility in honeybees (Apis mellifera): how anarchistic workers evade policing by laying eggs that have low removal rates. Behav. Ecol. Sociobiol. 47:268-73

82. Passera L, Aron S, Vargo EL, Keller L. 2001. Queen control of sex ratio in fire ants. Science 293:1308-10

83. Pirk CWW, Neumann P, Ratnieks FLW. 2003. Cape honeybees, Apis mellifera capensis, police worker-laid eggs despite the absence of relatedness benefits. $\mathrm{Be}$ hav. Ecol. 14:347-52

Pomeroy N. 1979. Brood bionomics of Bombus ruderatus in New Zealand (Hymenoptera: Apidae). Can. Entomol. 111:865-74

Queller DC, Zacchi F, Cervo R, Turillazzi S, Henshaw MT, et al. 2000. Unrelated helpers in a social insect. Nature 405:784-7

Ratnieks FLW. 1988. Reproductive harmony via mutual policing by workers in eusocial Hymenoptera. Am. Nat. 132:217-36

Ratnieks FLW. 1991. The evolution of genetic odor-cue diversity in social Hymenoptera. Am. Nat. 137:202-26

88. Ratnieks FLW. 1993. Egg-laying, eggremoval, and ovary development by workers in queenright honey-bee colo- 
nies. Behav. Ecol. Sociobiol. 32:191-8

89. Ratnieks FLW. 1995. Evidence for a queen-produced egg-marking pheromone and its use in worker policing in the 99 . honey-bee. J. Apic. Res. 34:31-7

90. Ratnieks FLW. 2001. Heirs and spares: caste conflict and excess queen production in Melipona bees. Behav. Ecol. Sociobiol. 50:467-73

91. Ratnieks FLW, Reeve HK. 1992. Conflict in single-queen hymenopteran societies: the structure of conflict and processes that reduce conflict in advance eusocial species. J. Theor. Biol. 158:3365

92. Ratnieks FLW, Visscher PK. 1989. Worker policing in the honeybee. Nature 342:796-7

93. Reed HC, Akre RD. 1983. Comparative colony behavior of the forest yellowjacket, Vespula acadica (Sladen) (Hymenoptera: Vespidae). J. Kans. Entomol. Soc. 56:581-606

94. Saigo T, Tsuchida K. 2004. Queen and worker policing in monogynous and monandrous colonies of a primitively eusocial wasp. Proc. R. Soc. London Ser. B Biol. Sci. (Suppl.) 271:S509-S12

95. Sakagami SF. 1954. Occurrence of an aggressive behaviour on queenless hives, with considerations on the social organisation of honeybee. Insect Sociaux 14:331-43

96. Sakagami SF, Oniki Y. 1963. Behavior studies of the stingless bees, with special reference to the oviposition process. I. Melipona compressipes manaosensis Schwarz. J. Fac. Sci. Hokk. Univ. Ser. VI 15:300-18

97. Sakagami SF, Zucchi R. 1965. Winterverhalten einer neotropischen Hummel, Bombus atratus, innerhalb des Biobachtungskastens. Ein Beitrag zur Biologie der Hummeln. J. Fac. Sci. Hokk. Univ. Ser. VI 15:712-62

98. Schmid-Hempel R, Schmid-Hempel P.
2000. Female mating frequencies in Bombus spp. from Central Europe. Insectes Soc. 47:36-41

Sladen FWL. 1912. The Humble-bee, its Life-History and how to Domesticate it. London: Macmillan and Co.

100. Sommeijer MJ, Houtekamer JL, Bos W. 1984. Cell construction and egg-laying in Trigona nigra paupera with a note on the adaptive significance of oviposition behavior of stingless bees. Insectes Soc. 31:199-217

Tsuchida K, Saigo T, Nagata N, Tsujita S, Takeuchi K, et al. 2003. Queenworker conflicts over male production and sex allocation in a primitively eusocial wasp. Evolution 57:2365-73

102. Tsuchida K, Saigo T, Takeuchi K. 2002. Queen-worker conflict over male production in a Japanese paper wasp Polistes chinensis antennalis. Presented at Proceedings of the XIVth International Congress of the IUSSI, Sapporo, Japan

103. van Honk CGJ, Röseler PF, Velthuis HHW, Hoogeveen JC. 1981. Factors influencing the egg laying of workers in a captive Bombus terrestris colony. Behav. Ecol. Sociobiol. 9:9-14

104. van Walsum E, Gobin B, Ito F, Billen J. 1998. Worker reproduction in the ponerine ant Odontomachus simillimus (Hymenoptera: Formicidae). Sociobiology 32:427-40

105. Velthuis HHW, Alves DdA, ImperatrizFonseca VL, Duchateau MJ. 2002. Worker bees and the fate of their eggs. Proc. Sect. Exp. Appl. Entomol. Neth. Entomol. Soc. 13: 97-102

106. Visscher KP, Dukas R. 1995. Honey bees recognize development of nestmates' ovaries. Anim. Behav. 49:542-4

107. Wenseleers T, Badcock NS, Erven K, Tofilski A, Nascimento FS, et al. 2005. A test of worker policing theory in an advanced eusocial wasp, Vespula rufa. Evolution 59:1306-14 
108. Wenseleers T, Hart AG, Ratnieks FLW. 2004. When resistance is useless: policing and the evolution of reproductive acquiescence in insect societies. Am. Nat. 164:E154-E67

109. Wenseleers T, Helanterä H, Hart AG, Ratnieks FLW. 2004. Worker reproduction and policing in insect societies: an ESS analysis. J. Evol. Biol. 17:1035-47

110. Wenseleers T, Ratnieks FLW. Comparative analysis supports relatedness theory for worker policing in eusocial Hymenoptera. Submitted

111. Wenseleers T, Ratnieks FLW. Effective sanctions deter worker reproduction in wasp societies. Submitted

112. Wenseleers T, Ratnieks FLW, Billen J.
2003. Caste fate conflict in swarmfounding social Hymenoptera: an inclusive fitness analysis. J. Evol. Biol. 16:647-58

113. Wenseleers T, Tofilski A, Nascimento FS, Ratnieks FLW. Infighting among workers helps queen in an advanced eusocial wasp. Submitted

114. Wenseleers T, Tofilski A, Ratnieks FLW. 2005. Queen and worker policing in the tree wasp Dolichovespula sylvestris. Behav. Ecol. Sociobiol. 58:80-6

115. Wenseleers T, Tofilski A, Ratnieks FLW. From egg-laying competition to worker policing: a proposed evolutionary scenario. Submitted 